\title{
Metabotropic Glutamate Receptor 8-Expressing Nerve Terminals Target Subsets of GABAergic Neurons in the Hippocampus
}

\author{
Francesco Ferraguti, ${ }^{1,2}$ Thomas Klausberger, ${ }^{1,3}$ Philip Cobden, ${ }^{1}$ Agnes Baude,,${ }^{1,4}$ J. David B. Roberts, ${ }^{1}$ Peter Szucs, ${ }^{5}$ \\ Ayae Kinoshita, ${ }^{6}$ Ryuichi Shigemoto, ${ }^{7}$ Peter Somogyi, ${ }^{1}$ and Yannis Dalezios ${ }^{1,8}$ \\ ${ }^{1}$ Medical Research Council Anatomical Neuropharmacology Unit, Department of Pharmacology, Oxford University, Oxford OX1 3TH, United Kingdom, \\ ${ }^{2}$ Department of Pharmacology, Innsbruck Medical University, A-6020 Innsbruck, Austria, ${ }^{3}$ Centre for Brain Research, Medical University Vienna, A-1090 \\ Vienna, Austria, ${ }^{4}$ Laboratoire de NeuroPhysiologie Cellulaire, Centre National de la Recherche Scientifique, Unité Mixte de Recherche 6150, 13402 Cedex 20 \\ Marseille, France, ${ }^{5}$ Department of Anatomy, Histology, and Embryology, Faculty of Medicine, Medical and Health Centre, University of Debrecen, H-4012 \\ Debrecen, Hungary, ${ }^{6}$ Horizontal Medical Research Organization, Kyoto University Graduate School of Medicine, Kyoto 606-8501, Japan, ${ }^{7}$ Division of \\ Cerebral Structure, National Institute for Physiological Sciences, Okazaki 444-8787, Japan, and ${ }^{8}$ Department of Basic Sciences, Faculty of Medicine, \\ University of Crete, GR-71003 Heraklion, Greece
}

Presynaptic metabotropic glutamate receptors (mGluRs) show a highly selective expression and subcellular location in nerve terminals modulating neurotransmitter release. We have demonstrated that alternatively spliced variants of mGluR8, mGluR8a and mGluR8b, have an overlapping distribution in the hippocampus, and besides perforant path terminals, they are expressed in the presynaptic active zone of boutons making synapses selectively with several types of GABAergic interneurons, primarily in the stratum oriens. Boutons labeled for mGluR8 formed either type I or type II synapses, and the latter were GABAergic. Some mGluR8-positive boutons also expressed mGluR7 or vasoactive intestinal polypeptide. Interneurons strongly immunopositive for the muscarinic M2 or the mGlu1 receptors were the primary targets of mGluR8-containing terminals in the stratum oriens, but only neurochemically distinct subsets were innervated by mGluR8-enriched terminals. The majority of M2-positive neurons were mGluR8 innervated, but a minority, which expresses somatostatin, was not. Rare neurons coexpressing calretinin and $\mathrm{M} 2$ were consistently targeted by mGluR8-positive boutons. In vivo recording and labeling of an mGluR8-decorated and strongly M2-positive interneuron revealed a trilaminar cell with complex spike bursts during theta oscillations and strong discharge during sharp wave/ripple events. The trilaminar cell had a large projection from the CA1 area to the subiculum and a preferential innervation of interneurons in the CA1 area in addition to pyramidal cell somata and dendrites. The postsynaptic interneuron type-specific expression of the high-efficacy presynaptic mGluR8 in both putative glutamatergic and in identified GABAergic terminals predicts a role in adjusting the activity of interneurons depending on the level of network activity.

Key words: presynaptic; immunogold labeling; muscarinic receptors; inhibition; network oscillation; hippocampus

\section{Introduction}

The highly regulated distribution of neurotransmitter receptors is an important determinant of neuronal networks. In particular, the remarkable molecular diversity, cell-specific expression, and discrete targeting to defined domains in the plasma membrane of

Received June 21, 2005; revised Sept. 9, 2005; accepted 0ct. 2, 2005.

This work was supported in part by the Fonds zur Förderung der wissenschaftlichen Forschung (Grant P16720 to F.F.) and the Wellcome Trust (Advanced Training Fellowship to Y.D.). We thank Dr. Laszlo Marton for help in the reconstruction of the trilaminar cell, shown in Figure 8, and G. Schmid and B. Micklem for excellent technical support. We are grateful to the following for the gift of antibodies: Dr. A. Buchan (Medical Research Council Regulatory Peptide Group, Vancouver, British Columbia, Canada), Dr. K. Tanaka (Niigata University, Niigata, Japan), Dr. A. Varro (Liverpool University, Liverpool, UK), Dr. K. G. Baimbridge (University of British Columbia, Vancouver, British Columbia, Canada), Dr. J. Polak (Imperial College, London, UK), and Dr. B. Gasnier (Centre National de la Recherche Scientifique-Institut de Biologie Physico-Chimique, Paris, France).

Correspondence should be addressed to Dr. Francesco Ferraguti, Department of Pharmacology, Innsbruck Medical University, Peter Mayr Strasse 1A, A-6020 Innsbruck, Austria. E-mail: francesco.ferraguti@uibk.ac.at. DOI:10.1523/JNEUROSCI.2547-05.2005

Copyright $\odot 2005$ Society for Neuroscience 0270-6474/05/2510520-17\$15.00/0 glutamate and GABA receptors underlie neuronal information processing.

Metabotropic glutamate receptors (mGluRs), heptahelical transmembrane receptors coupled to G-proteins, are encoded by eight different genes and contribute in regulating neuronal excitability and synaptic transmission (Nakanishi et al., 1994; Conn and Pin, 1997). In the hippocampus, mGluRs are expressed in a cell type-specific and subcellular domain-specific manner (Shigemoto et al., 1996, 1997; Somogyi et al., 2003; Ferraguti et al., 2004). Based on phylogenetic analysis, intracellular coupling, and pharmacology (Conn and Pin, 1997; Joost and Methner, 2002), mGluRs can be subdivided into three structurally and functionally homologous subgroups: group I (mGluR1 and mGluR5), primarily located postsynaptically (Baude et al., 1993; Lujan et al., 1996); group II (mGluR2 and mGluR3), present both postsynaptically and presynaptically outside the release site (Shigemoto et al., 1997; Tamaru et al., 2001); and group III 
(mGluR4, mGluR6-mGluR8), found in the presynaptic active zone (Shigemoto et al., 1996; Shigemoto and Mizuno, 2000; Corti et al., 2002; Somogyi et al., 2003).

A consequence of group III mGluR activation is the depression of both glutamatergic and GABAergic transmission (Schoepp, 2001). The complement of different group III mGluRs at distinct synapses plays a differential role in determining the specific physiological behavior of neuronal responses (Shigemoto et al., 1996; Scanziani et al., 1998; Evans et al., 2000; Semyanov and Kullmann, 2000). For example, in the hippocampal CA1 area, high levels of mGluR4 (Corti et al., 2002; Kogo et al., 2004), mGluR7a (Shigemoto et al., 1996, 1997; Kogo et al., 2004), and mGluR7b (Somogyi et al., 2003) are present in the presynaptic active zone of distinct sets of synapses with different dynamics. However, the known location of group III mGluR subtypes cannot explain pharmacological results on the regulation of synaptic transmission by this class of receptors (Scanziani et al., 1998; Semyanov and Kullmann, 2000; Losonczy et al., 2003; Kogo et al., 2004). The reported results suggest a significant role for the high-efficacy group III mGluRs, such as mGluR8, in regulating transmitter release depending on the identity of specific circuits. Immunoreactivity for mGluR8a was predominantly reported in the termination zone of the lateral perforant pathway in the dentate gyrus and CA3 area, although scattered labeling was also found in other strata of CA areas (Shigemoto et al., 1997; Kogo et al., 2004) with unidentified synaptic partners.

The aim of the present study has been the definition of the precise distribution of mGluR8 splice variants (Corti et al., 1998) in the hippocampus in relation to synaptic sites and the characterization of the neurochemical nature of the target neurons receiving mGluR8-expressing inputs. In addition, we report the network-related firing patterns of an interneuron that belongs to a nonpyramidal cell class selectively targeted by mGluR8acontaining boutons. Preliminary results were published in abstract form (Dalezios et al., 2001).

\section{Materials and Methods}

All procedures involving experimental animals were performed in accordance with the United Kingdom Animals (Scientific Procedures) Act 1986 and associated procedures. All efforts were made to minimize stress to the animals and the number of animals used. For immunocytochemical studies, 16 adult Wistar rats (300-400 g; Charles River, Margate, Kent, UK) were deeply anesthetized with Sagatal (pentobarbitone sodium; $100 \mathrm{mg} / \mathrm{kg}$, i.p.) and perfused transcardially with saline, followed for $15 \mathrm{~min}$ by a fixative composed of $4 \%$ paraformaldehyde, $\sim 0.2 \%$ picric acid, and $0.05 \%$ glutaraldehyde in $0.1 \mathrm{~m}$ phosphate buffer $(\mathrm{PB}), \mathrm{pH}$ 7.2-7.4. For immunofluorescence studies, no glutaraldehyde was included in the fixative. The brains were removed quickly, rinsed extensively in $\mathrm{PB}$, and sectioned in the coronal plane on a vibratome at $50 \mu \mathrm{m}$ thickness for immunofluorescence studies and at $70 \mu \mathrm{m}$ thickness for electron microscopy.

Antibodies. A complete list of the primary and secondary antibodies, including their dilution and combined use, used for this study is given in Table 1. All secondary antibodies were purchased from commercial sources (Table 1), as well as several primary antibodies: mouse antivasoactive intestinal polypeptide (VIP) and rabbit anti-calretinin (CR) from Biogenesis (Poole, UK); rabbit anti-VIP from Euro-diagnostica (Boldon, UK); rat anti-muscarinic type 2 receptor (M2) and guinea pig anti-substance P receptor (NK1) from Chemicon (Chandlers Ford, UK); rabbit anti-mGluRla from DiaSorin (Stillwater, MN); mouse antiparvalbumin (PV) from Sigma-Aldrich (Gillingham, UK); and rabbit anti-calbindin (CB-38, lot 5.5), mouse anti-CR, and mouse and rabbit anti-PV from Swant (Bellinzona, Switzerland). Other primary antibodies were kindly provided by the following: Dr. A. Buchan (Medical Research Council Regulatory Peptide Group, Vancouver, British Columbia, Can- ada), mouse anti-somatostatin (SOM) (Vincent et al., 1985); Dr. K. Tanaka (Niigata University, Niigata, Japan), human anti-glutamic acid decarboxylase (GAD) (Oe et al., 1996); Dr A. Varro (Liverpool University, Liverpool, UK), rabbit anti-procholecystokinin (CCK) (Morino et al., 1994); Dr. K.G. Baimbridge (University of British Columbia, Vancouver, British Columbia, Canada), guinea pig anti-PV (Ferraguti et al., 2004); Dr. J. Polak (Imperial College, London, UK), rabbit antineuropeptide Y (NPY) (Allen et al., 1983); and Dr. B. Gasnier (Centre National de la Recherche Scientifique-Institut de Biologie PhysicoChimique, Paris, France), rabbit anti-vesicular GABA transporter (VIAAT) (Dumoulin et al., 1999). The polyclonal antibodies against mGluR7a, mGluR8b, and NK1, raised in rabbit, and mGluR8a, raised in guinea pig, were generated and characterized as described previously (Shigemoto et al., 1993, 1996, 1997; Kinoshita et al., 1996; Somogyi et al., 2004).

Immunoblotting of cell membranes. To assess the specificity of the mGluR8 isoform-specific antibodies, cDNAs encoding rat mGluR8a and mGluR8b (Corti et al., 1998) were subcloned into the eukaryotic expression vector pcDNA3 (Invitrogen, San Giuliano Milanese, Italy) and transfected into subconfluent $\mathrm{CHO}-\mathrm{K} 1$ cells grown in DMEM (Life Technologies, Paisley, UK) in the presence of $10 \%$ fetal bovine serum. Transfections were performed with a solution containing $10 \mu \mathrm{g}$ of cDNA and a 3:1 ratio of FuGene reagent (Roche Diagnotics, Rotkreuz, Switzerland) in $200 \mu \mathrm{l}$ of serum-free DMEM per $10 \mathrm{~cm}$ dish for $30 \mathrm{~min}$. After $48 \mathrm{~h}$, cells were harvested, resuspended with $200 \mu$ l of lysis buffer $(20 \mathrm{~mm}$ Tris base, $150 \mathrm{~mm} \mathrm{NaCl}, 50 \mu \mathrm{M}$ phenylmethylsulfonyl fluoride, $1 \mu \mathrm{g} / \mathrm{ml}$ leupeptin, $1 \mu \mathrm{g} / \mathrm{ml}$ pepstatin A, $1 \mu \mathrm{g} / \mathrm{ml}$ aprotinin, $1 \mu \mathrm{g} / \mathrm{ml}$ bacitracin, 10 $\mu \mathrm{g} / \mathrm{ml}$ bestatin, $1 \mu \mathrm{g} / \mathrm{ml}$ antipain, and $1 \mu \mathrm{g} / \mathrm{ml}$ chymostatin), and sonicated twice. All chemicals were purchased from Sigma (St. Louis, MO).

Total proteins of cell lysate ( $10 \mu \mathrm{g} / \mathrm{lane})$, quantified by the bicinchoninic acid protein assay (Pierce, Rockford, IL), were denatured in Laemmli sample buffer containing $20 \mathrm{~mm}$ dithiothreitol (DTT) and heated for $3 \mathrm{~min}$ at $60^{\circ} \mathrm{C}$ for SDS-PAGE on an $8 \%$ resolving gel. Proteins were then electrophoretically transferred to polyvinylidene difluoride membranes (Hybond P; Amersham Biosciences, Little Chalfont, UK). Blots were blocked for $1 \mathrm{~h}$ in $5 \%$ dried skimmed milk in $0.9 \% \mathrm{NaCl}$ buffered with $50 \mathrm{~mm}$ Tris (TBS) $-0.1 \%$ Tween 20 and incubated overnight at $4^{\circ} \mathrm{C}$ with anti-mGluR8a $(0.6 \mu \mathrm{g} / \mathrm{ml})$ or anti-mGluR8b $(0.5 \mu \mathrm{g} / \mathrm{ml})$ antibodies. Immunodetection was performed with secondary antibodies [1:2000 anti-rabbit IgG from donkey, NA934 (Amersham Biosciences); or 1:1000 anti-guinea pig IgG from rabbit, P0141 (Dako, Glostrup, Denmark)] conjugated to horseradish peroxidase (HRP) and performed by enhanced chemiluminescence (Amersham Biosciences).

Double- and triple-immunofluorescent experiments. Immunofluorescent experiments were performed according to procedures published previously (Ferraguti et al., 2004). Briefly, free-floating sections were incubated in blocking solution [TBS, pH 7.4, 0.1\% Triton X-100 (TX), and $20 \%$ normal goat serum (NGS)] for $1 \mathrm{~h}$ and then in primary antibodies (see Table 1 for complete listing and dilutions), in combination or alone, diluted in TBS, $0.1 \% \mathrm{TX}$, and $1 \% \mathrm{NGS}$ for $\sim 48 \mathrm{~h}\left(4^{\circ} \mathrm{C}\right)$. Subsequently, after extensive washes in TBS, sections were incubated overnight $\left(4^{\circ} \mathrm{C}\right.$ ) with a mixture of appropriate secondary antibodies (Table 1 ). When biotinylated secondary antibodies were used, sections were subsequently incubated, after extensive washes in TBS, in a solution containing streptavidin conjugated to either 7-amino-4-methylcoumarin-3acetic acid (1:1000; Vector Laboratories, Burlingame, CA) or Cy5 (1: 1000; Amersham Biosciences) diluted in TBS-0.1\% TX. When biotinylated HRP-conjugated secondary antibodies were used, sections were subsequently incubated, after extensive washes in TBS, in the FITCtyramide reagent (PerkinElmer Life Sciences, Boston, MA) diluted 1:50 in amplification diluent for $10 \mathrm{~min}$. Sections were then mounted onto gelatin-coated slides in Vectashield (Vector Laboratories).

Image acquisition and analysis. Immunofluorescence was studied using a Leitz (Wetzlar, Germany) DMRB microscope with epifluorescence illumination equipped with the following filter blocks: A4 (excitation filter band pass (BP), 360/40 nm; reflection short-pass filter, $400 \mathrm{~nm}$; suppression filter BP, $470 / 40 \mathrm{~nm}$ ), L5 (excitation filter BP, 480/40 nm; reflection short-pass filter, $505 \mathrm{~nm}$; suppression filter BP, 527/30 nm), Y3 (excitation filter BP, 545/30 nm; reflection short-pass filter, $565 \mathrm{~nm}$; suppres- 
Table 1. Summary of the concentrations and combinations of primary and secondary antibodies

\begin{tabular}{|c|c|c|c|c|c|}
\hline Primary antibodies & Species (raised in) & Dilution & Secondary antibodies & Dilution & Reactions \\
\hline \multirow[t]{5}{*}{ mGluR8a } & \multirow[t]{5}{*}{ Guinea pig } & $1: 500$ & Gt anti-GP biotin ${ }^{a}$ & $1: 100$ & $27,30,31,32,33$ \\
\hline & & $1: 500$ & Gt anti-GP nanogold ${ }^{b}$ & $1: 100$ & 26 \\
\hline & & $1: 500$ & Gt anti-GP Alexa $488^{c}$ & $1: 1000$ & $3,4,5,7,11,12,13,14,17,21,24,34$ \\
\hline & & $1: 500$ & Dnk anti-GP FITC ${ }^{d}$ & $1: 400$ & 8,9 \\
\hline & & $1: 500$ & Dnk anti-GP CyзTM ${ }^{d}$ & $1: 400$ & $1,10,15,16,18,19,20,22,23,25$ \\
\hline \multirow[t]{4}{*}{ mGluR8b } & \multirow[t]{4}{*}{ Rabbit } & $1: 200$ & Dnk anti-Rb Cyз TM $^{d}$ & $1: 400$ & 2,3 \\
\hline & & $1: 200$ & Gt anti-Rb Alexa $488^{c}$ & 1:1000 & 6 \\
\hline & & $1: 200$ & $\mathrm{Gt}_{\text {anti-Rb biotin }}{ }^{a}$ & $1: 100$ & 28 \\
\hline & & $1: 200$ & Gt anti-Rb nanogold ${ }^{b}$ & $1: 100$ & 29 \\
\hline CCK & Rabbit & $1: 1000$ & Dnk anti-Rb Cyз3M ${ }^{d}$ & $1: 400$ & 14 \\
\hline \multirow[t]{4}{*}{$\mathrm{CR}$} & \multirow[t]{4}{*}{ Mouse } & $1: 500$ & Gt anti-Ms Cy3TM ${ }^{d}$ & $1: 400$ & 13 \\
\hline & & $1: 2000$ & Gt anti-Ms Alexa $488^{c}$ & $1: 1000$ & 23 \\
\hline & & $1: 2000$ & Gt anti-Ms AMCA ${ }^{e}$ & $1: 100$ & 20 \\
\hline & & $1: 2000$ & Gt anti-Ms Cy5TM ${ }^{f}$ & $1: 500$ & 21,24 \\
\hline \multirow[t]{2}{*}{$C R$} & \multirow[t]{2}{*}{ Rabbit } & $1: 800$ & Dnk anti-Rb Cyз TM $^{d}$ & $1: 400$ & 9,35 \\
\hline & & $1: 800$ & Gt anti-Rb Cy5TM ${ }^{f}$ & $1: 1000$ & 10,22 \\
\hline \multirow[t]{2}{*}{ Calbindin } & \multirow[t]{2}{*}{ Rabbit } & $1: 10,000$ & Dnk anti-Rb CyзTM ${ }^{d}$ & $1: 400$ & 11 \\
\hline & & $1: 10,000$ & Dnk anti-Rb Cyз $\mathrm{TM}^{d}$ & $1: 400$ & 34 \\
\hline $\mathrm{GAD}$ & Human & $1: 1000$ & Gt anti-HS nanogold ${ }^{b}$ & $1: 100$ & 30 \\
\hline \multirow[t]{5}{*}{ M2 } & \multirow[t]{5}{*}{ Rat } & $1: 250$ & Gt anti-Rat CузтM ${ }^{d}$ & $1: 400$ & $4,5,6$ \\
\hline & & $1: 250$ & Gt anti-Ms Cy5TM ${ }^{d}$ & $1: 500$ & 7,36 \\
\hline & & $1: 250$ & Gt anti-Ms biotin ${ }^{a}$ & $1: 100$ & $8,9,11$ \\
\hline & & $1: 500$ & Dnk anti-Rat Cy2TM ${ }^{d}$ & $1: 400$ & 10 \\
\hline & & $1: 200$ & Gt anti-Ms nanogold ${ }^{b}$ & $1: 100$ & 32 \\
\hline \multirow[t]{4}{*}{ mGluR1a } & \multirow[t]{4}{*}{ Rabbit } & $1: 500$ & Gt anti-Rb nanogold ${ }^{b}$ & $1: 100$ & 33 \\
\hline & & $1: 500$ & Gt anti-Rb Cy5TM ${ }^{f}$ & 1:1000 & 5 \\
\hline & & $1: 500$ & Gt anti-Rb Alexa $488^{c}$ & 1:1000 & $15,16,19,20$ \\
\hline & & $1: 500$ & Dnk anti-Rb СузтM ${ }^{d}$ & $1: 400$ & $7,17,21,34,37$ \\
\hline \multirow[t]{2}{*}{ mGluR7a } & \multirow[t]{2}{*}{ Rabbit } & $1: 500$ & Dnk anti-Rb Alexa 488c & $1: 1000$ & 18 \\
\hline & & $1: 500$ & Dnk anti-Rb CyзTM ${ }^{d}$ & $1: 400$ & 36 \\
\hline NK1 receptor & Rabbit & $1: 1000$ & Dnk anti-Rb Cyз $\mathrm{TM}^{d}$ & $1: 400$ & 34 \\
\hline NK1 receptor & Guinea pig & $1: 500$ & Gt anti-Gp Alexa $488^{c}$ & 1:1000 & 35 \\
\hline NPY & Rabbit & $1: 2000$ & Dnk anti-Rb CузтM ${ }^{d}$ & $1: 400$ & 35 \\
\hline \multirow[t]{2}{*}{ PV } & \multirow[t]{2}{*}{ Mouse } & $1: 10,000$ & Hrs anti-Ms biotin ${ }^{a}$ & $1: 100$ & 17 \\
\hline & & $1: 10,000$ & Gt anti-Ms AMCA & $1: 100$ & 16 \\
\hline PV & Guinea pig & $1: 1000$ & Gt anti-GP Alexa $488^{c}$ & $1: 1000$ & 35 \\
\hline \multirow[t]{4}{*}{ SOM } & \multirow[t]{4}{*}{ Mouse } & $1: 500$ & Gt anti-Ms biotin ${ }^{a}$ & $1: 100$ & 8 \\
\hline & & $1: 500$ & Gt anti-Ms CузтM ${ }^{d}$ & $1: 400$ & 12 \\
\hline & & $1: 500$ & Gt anti-Ms AMCA & $1: 100$ & 15 \\
\hline & & $1: 500$ & Gt anti-Ms Cy5TM ${ }^{d}$ & $1: 500$ & $18,34,35$ \\
\hline Streptavidin-AMCA & & $1: 1000$ & Streptavidin-AMCA ${ }^{a}$ & 1:1000 & $25,34,35,36,37$ \\
\hline VIAAT & Rabbit & $1: 2000$ & Gt anti-Rb nanogold ${ }^{b}$ & $1: 100$ & 31 \\
\hline \multirow[t]{2}{*}{ VIP } & \multirow[t]{2}{*}{ Mouse } & $1: 10,000$ & Gt anti-Ms AMCA & $1: 100$ & 19 \\
\hline & & $1: 10,000$ & Gt anti-Ms Alexa $488^{c}$ & 1:1000 & 22 \\
\hline \multirow[t]{2}{*}{ VIP } & Rabbit & $1: 2000$ & Dnk anti-Rb Cyз TM $^{d}$ & $1: 400$ & 24 \\
\hline & & $1: 2000$ & Gt anti-Rb Cy5TM ${ }^{f}$ & $1: 1000$ & 23 \\
\hline
\end{tabular}

Gt, Goat; Dnk, donkey; Ms, mouse; Rb, rabbit; Hrs, horse; GP, guinea pig.

${ }^{a}$ Purchased from Vector Laboratories.

${ }^{b}$ Purchased from Nanoprobes.

'Purchased from Invitrogen (Eugene, OR).

${ }^{d}$ Purchased from Jackson ImmunoResearch (West Grove, PA).

ePurchased from MP Biomedicals (Irvine, CA).

fPurchased from Amersham Biosciences.

sion filter $\mathrm{BP}, 610 / 75 \mathrm{~nm}$ ), and Y5 (excitation filter BP, 620/60 nm; reflection short-pass filter, $660 \mathrm{~nm}$; suppression filter BP, 700/75 nm). Images, recorded through a CCD camera (model C4742-95; Hamamatsu, Welwyn Garden City, UK), were analyzed and displayed using the Openlab software (version 3.1.4; Improvision, Coventry, UK). Brightness and contrast were adjusted for the entire frame, and no part of a frame was modified in any way. For the colocalization of mGluR7a and mGluR8a immunolabeling in terminals, specimens were analyzed with a Zeiss (Oberkochen, Germany) LSM 510/Axiovert 100M confocal microscope.

Immunocytochemistry for electron microscopy. The immunocytochemical procedures were identical to those described previously (Dalezios et al., 2002). Floating sections were first incubated for $1 \mathrm{~h}$ in $20 \%$ NGS diluted in TBS. Sections were then incubated with primary antibodies (Table 1) in TBS containing 1\% NGS, at least overnight or for several days. When a single primary antibody was used, it was visualized either by an immunoperoxidase method or by silver-intensified immunogold reaction. When more than one primary antibody was used, one of them was visualized by immunoperoxidase reaction and the second one was visualized by silver-intensified immunogold reaction. After primary antibody incubation, the sections were incubated overnight at $4^{\circ} \mathrm{C}$ in one, or in a mixture, of the secondary antibodies (Table 1). Fab fragment IgG coupled to $1.4 \mathrm{~nm}$ gold was purchased from Nanoprobes (Stony Brook, NY). After several washes in TBS, when required, the sections were 
washed in double-distilled water, followed by silver enhancement of the gold particles with an HQ Silver kit (Nanoprobes) for 8-12 min. Subsequently, the sections were incubated in avidin-biotinylated HRP complex (diluted 1:100; Vector Laboratories) in TBS overnight at $4^{\circ} \mathrm{C}$ and washed in Tris buffer, $\mathrm{pH} \sim 7.4$. Peroxidase was visualized with 3-3'diaminobenzidine (DAB; $0.5 \mathrm{mg} / \mathrm{ml}$ ) using $0.01 \% \mathrm{H}_{2} \mathrm{O}_{2}$ as substrate for 5-10 min. Sections were then treated with $2 \% \mathrm{OsO}_{4}$, contrasted with $1 \%$ uranyl-acetate, and embedded in epoxy resin (Durcupan ACM, Fluca; Sigma-Aldrich, Gillingham, UK). Ultrathin (70- to 80-nm-thick) serial sections were collected on pioloform-coated copper grids and analyzed in a Philips (Eindhoven, The Netherlands) CM100 electron microscope. Unless stated otherwise, samples were obtained at least from two different rat brains, and two blocks of each animal were cut for electron microscopy.

Controls. To test antibody and method specificity in the procedures for light or electron microscopy, antisera against mGluR1a, mGluR7a, mGluR8a, and mGluR8b used in this study were tested on brain slices of mice lacking the respective receptor [brains of receptor-null mice were kindly provided by Dr. F. Conquet (Institut de Biologie Cellulaire et de Morphologie, Université de Lausanne, Lausanne, Switzerland), Dr. R. Duvoisin (Neurological Sciences Institute, Oregon Health \& Science University, Portland, OR), and Dr. Van der Putten (Neuroscience Research, Novartis Institutes for Biomedical Research, Novartis Pharma AG, Basel Switzerland)]. No immunolabeling for any of these antibodies could be detected in sections of mice lacking the respective receptor (data not shown).

To control for a possible cross-reactivity between IgGs in double- and triple-immunolabeling experiments, some sections were processed through the same immunocytochemical sequence, except that only one primary antibody was applied; but the full complement of secondary antibodies was maintained. In addition, the secondary antibodies used were highly pre-adsorbed to the IgGs of numerous species.

In situ hybridization. In situ hybridization experiments were performed as described previously (Shigemoto et al., 1992; Ohishi et al., 1993). Briefly, adult male Sprague Dawley rats $(n=2 ; 250-300 \mathrm{~g})$ were deeply anesthetized with ether and decapitated. The brains were removed quickly and frozen in isopenthane at $-70^{\circ} \mathrm{C}$. Brains were subsequently cut at $10 \mu \mathrm{m}$ thickness on a cryostat and thaw-mounted onto poly-Llysine-coated slides. Sections were fixed with $4 \%$ paraformaldehyde in $0.1 \mathrm{M}$ PBS for $10 \mathrm{~min}$, rinsed in PBS, and acetylated with $0.25 \%$ acetic anhydride in $0.1 \mathrm{M}$ triethanolamine $/ 0.9 \% \mathrm{NaCl}$ for $10 \mathrm{~min}$ at room temperature. After dehydration in an ascending ethanol series, the sections were air dried and stored at $-80^{\circ} \mathrm{C}$ until use. Sections were hybridized with ${ }^{35}$ S-labeled antisense riboprobe corresponding to the $1-1378 \mathrm{bp}$ of rat mGluR8 (GenBank accession number U63288). Hybridization was performed in 50\% formamide, $2 \times$ SSC, $10 \mathrm{~mm}$ Tris-Hcl, $\mathrm{pH} 7.5,1 \times$ Denhardt's solution, $10 \%$ dextran sulfate, $0.2 \%$ SDS, 100 mM DTT, 500 $\mu \mathrm{g} / \mathrm{ml}$ sheared single-stranded salmon sperm DNA, and $250 \mu \mathrm{g} / \mathrm{ml}$ yeast tRNA. The riboprobes were preheated at $80^{\circ} \mathrm{C}$ for $3 \mathrm{~min}$ in $1 \mathrm{M} \mathrm{DTT}$ and diluted in hybridization buffer to $1 \times 10^{5} \mathrm{cpm} / \mu \mathrm{l}$ before application to the sections. Hybridization was performed at $57^{\circ} \mathrm{C}$ for $5 \mathrm{~h}$. Slides were washed in $2 \times$ SSC and $10 \mathrm{~mm} \beta$-mercaptoethanol at room temperature and then at $60^{\circ} \mathrm{C}$ for $1 \mathrm{~h}$. Sections were treated with $20 \mu \mathrm{g} / \mathrm{ml}$ RNase A in $0.5 \mathrm{~m} \mathrm{NaCl}, 10 \mathrm{~mm}$ Tris-Hcl, pH 7.5, and $1 \mathrm{~mm}$ EDTA, followed by an additional wash at a final stringency of $0.1 \times$ SSC at $60^{\circ} \mathrm{C}$ for $1 \mathrm{~h}$. After dehydration in ethanol, sections were air dried and exposed to Amersham Biosciences Beta-max films or dipped in NTB2 emulsion diluted 1:1 in distilled water. After exposure for 3-6 weeks at $4^{\circ} \mathrm{C}$, the dipped slides were developed in Kodak (Rochester, NY) D-19 developer, fixed, and counterstained with cresyl violet. Control experiments were done in adjacent sections with the same labeled riboprobe in the presence of 100 -fold excess unlabeled probe.

In vivo recordings. A male Sprague Dawley rat (320 g) was anesthetized with $0.42 \mathrm{~g}$ of urethane, plus supplemental doses of ketamine and xylazine ( 20 and $2 \mathrm{mg} / \mathrm{kg}$, respectively) as needed; body temperature was maintained with a heating pad. Neuronal activity in the hippocampus was recorded extracellularly with a glass electrode $(25 \mathrm{M} \Omega)$ filled with $1.5 \%$ neurobiotin in $0.5 \mathrm{M} \mathrm{NaCl}$, and the local field potential (LFP) was recorded with the same electrode. Single-unit activity (sampling rate, 20
$\mathrm{kHz}$ ) and LFP (sampling rate, $800 \mathrm{~Hz}$ ) were filtered on-line between 0.8 and $5 \mathrm{kHz}$ and direct current- $220 \mathrm{~Hz}$, respectively.

Physiological data analysis. Theta epochs were detected by calculating the theta $(3-6 \mathrm{~Hz})$ to $\delta$ frequency $(2-3 \mathrm{~Hz})$ power ratio in $2 \mathrm{~s}$ windows of the LFP (Csicsvari et al., 1998). A ratio $>4$ in at least three consecutive windows marked theta episodes, and a ratio $<2$ in at least three consecutive windows indicated epochs that are called non-theta/non-sharp wave periods, which, in addition, lacked field ripples. Non-theta/nonsharp wave periods contained oscillations of $1 \mathrm{~Hz}$ and/or 2-3 Hz but were not further analyzed in this study, because of the large variability in cell activity and LFPs. The exact beginning and end of these periods were set manually.

The LFP was filtered at $90-140 \mathrm{~Hz}$ for the detection of sharp waveassociated ripples, and the power (root mean square amplitude) of the filtered signal was calculated in $10 \mathrm{~ms}$ windows. The threshold for ripple detection was set to $5 \mathrm{SDs}$ above the mean power. The beginning and the end of the sharp wave were set at which the power crossed 1 SD above the mean power. The highest oscillation amplitude was detected by means of a peak-finding algorithm. To evaluate the firing pattern of the neuron during sharp waves, ripple episodes were normalized. Because sharp waves are often not symmetric, the periods between the beginning of the ripple and the ripple maximum, and between the ripple maximum and the end of the ripple episode, were each divided into four bins, and spikes were sorted into bins. To determine the phase relationship between single spikes and the phase of theta or ripple cycles, the troughs of the oscillations were detected in the filtered signal (3-6 or 90-140 Hz). Each spike was assigned to a given phase (bin size, 18 or $36^{\circ}$ ) between the troughs $\left(0\right.$ and $\left.360^{\circ}\right)$, and all cycles were superimposed. Theta and ripple phases were analyzed using circular statistics. The discharge frequency of the cell during three different brain states (theta, sharp wave, and nontheta/non-sharp wave) was calculated by dividing the number of spikes by the summed duration of the respective brain state (Klausberger et al., 2003).

Labeling and visualization of in vivo recorded cell. After the collection of a sufficient number of spikes, the electrode was advanced toward the cell, and the cell was labeled juxtacellularly with neurobiotin by applying positive current steps (Pinault, 1996). Four hours after labeling, the rat was perfused with the same fixative as described above. Coronal sections of $65 \mu \mathrm{m}$ were cut on a vibratome. The labeled cell was then tested according to procedures published previously (Klausberger et al., 2003, 2004). Immunofluorescence experiments were performed as described above. Sections containing processes of the cell were incubated with AMCA-conjugated streptavidin (1:1000; Vector Laboratories) together with three different primary antibodies, followed by appropriate secondary antibodies (Table 1). When the cell was found immunonegative for a certain antibody, the result was well documented by taking several digital photographs, and on several occasions, the same section was re-reacted with a different primary antibody but the same secondary antibody. In each re-reaction, we checked the tissue in general, not only the labeled cell, for the appearance of new signals resulting from the new antibodies. Only if novel immunopositive cells and/or processes appeared in the appropriate fluorescence channel was the labeled cell evalutated for the second or third tier of molecules. Cells or parts of cells were considered immunonegative for a molecule when fluourescence was undetectable in the tested cell in an area where other cells were immunopositive.

All sections containing processes of the cell (also including those developed for immunofluorescence) were processed for visualization of neurobiotin by an HRP reaction end product to reconstruct the cell. For electron-microscopic analysis, all filled terminals found were photographed, and the nature of the postsynaptic target was determined.

\section{Results}

Labeling for the two mGluR8 splice variants, mGluR8a and mGluR 8b, was highly specific as shown by Western immunoblot data (Fig. 1A). Their respective immunoreactivity in the hippocampal formation of adult rats was entirely overlapping and highly discrete. Prominent immunostaining in the outer molecular layer of the dentate gyrus and stratum lacunosum molecu- 
lare of the CA3 field (Fig. $1 B$ ) confirmed and extended a previous study (Shigemoto et al., 1997). In addition, somata and dendrites in the subiculum, CA1, and CA3 subfields were also observed outlined by numerous intensely immunofluorescent puncta (Fig. 1C-E). This labeling, consistent with a presynaptic location, was highly selective for a subpopulation of neurons in the stratum oriens/alveus of the CA1 field with somata and dendrites oriented horizontally (Fig. 1C,D). Labeling for both mGluR8a and mGluR8b appeared always to coexist in the same terminals (Fig. $1 D$ ). Some neuronal profiles in the stratum pyramidale and radiatum also appeared to be associated with mGluR8 labeling, although to a lesser extent compared with the stratum oriens/alveus. In addition, a number of dendritic profiles surrounded by puncta immunolabeled for mGluR8 were observed at the border between the stratum radiatum and lacunosum moleculare (data not shown). In the CA3 area, neurons strongly outlined by mGluR8a- and mGluR8b-immunopositive boutons were commonly observed within the pyramidal cell layer (Fig. $1 E, F$ ).

\section{Distribution of mGluR8}

immunoreactivity in nerve terminals

The presynaptic location of mGluR8a and mGluR8b in the hippocampal CA1 area was tested by immunoelectron microscopy with either immunoperoxidase or silver-intensified immunogold methods. Labeling was restricted to boutons, which formed either type I (asymmetrical) synapses on dendritic shafts or type II (symmetrical) synapses on dendritic shafts and somatic profiles (Fig. 2). Immunogold particles were confined to the presynaptic active zone (Fig. $2 A, C, E, G, H$ ), whereas the amorphous electron opaque peroxidase product also diffused between presynaptic vesicles, filling, in some cases, the entire terminal (Fig. $2 B, D, F$ ). Each individual dendritic profile appeared to receive predominantly only one type of mGluR8immunopositive synapses (Fig. 3). This observation was confirmed for mGluR8a by quantitative analysis of dendrites located in the stratum oriens/alveus. Only dendritic profiles receiving at least one type I and one type II synapse on the sampled segment were included in the analysis, and each synapse was assessed in several consecutive sections to test whether they were immunopositive or not. Under these sampling criteria, we encountered 19 dendritic profiles, receiving 2-10 synapses each. Five possessed type I immunopositive synapses only, 12 received immunopositive terminals making type II synapses only, and only two had both type I and type II immunoreactive terminals on them. These dendrites are likely to belong to interneurons because they received type I synapses, which are not present on the dendritic shafts of pyramidal cells (Megias et al., 2001). To establish whether the restricted presence of mGluR8 in type I or II synapses on distinct dendrites was different from random, we first analyzed the frequency of distribution of the two types of synapse in the three different categories of mGluR8-decorated dendrites. The frequencies of total type I or type II synapses did not differ between categories of dendrites $\left(p>0.75 ; \chi^{2}\right.$ test). The frequencies of mGluR8-immunopositive and -immunonegative terminals were also not different among the three categories of dendrites $\left(p>0.05 ; \chi^{2}\right.$ test). Therefore, our sampling procedure did not favor the selection of specific terminals on some of the profiles. These findings allowed us to compute the expected occurrence of the four types of terminals (type I or type II, mGluR8a positive or negative) on each of the 19 profiles in our sample, as the product of the frequencies of the terminals. We found that the observed frequencies differed from random ( $p<0.05 ; \chi^{2}$ test). When the expected versus the observed frequencies were tested for each dendrite category, we found that for dendrites receiving mGluR8-immunopositive terminals only in type II synapses, the observed frequencies were significantly different $\left(p<0.0001 ; \chi^{2}\right.$ test) from expected, whereas for the other categories, no statistically significant differences were obtained ( $p<0.25 ; \chi^{2}$ test). In conclusion, these findings indicate that some dendritic profiles predominantly receive type II mGluR8a-immunopositive terminals. Whether these profiles comprise a specific type(s) of interneuron remains to be established.

In the stratum lacunosum moleculare, mGluR8-immuno- 


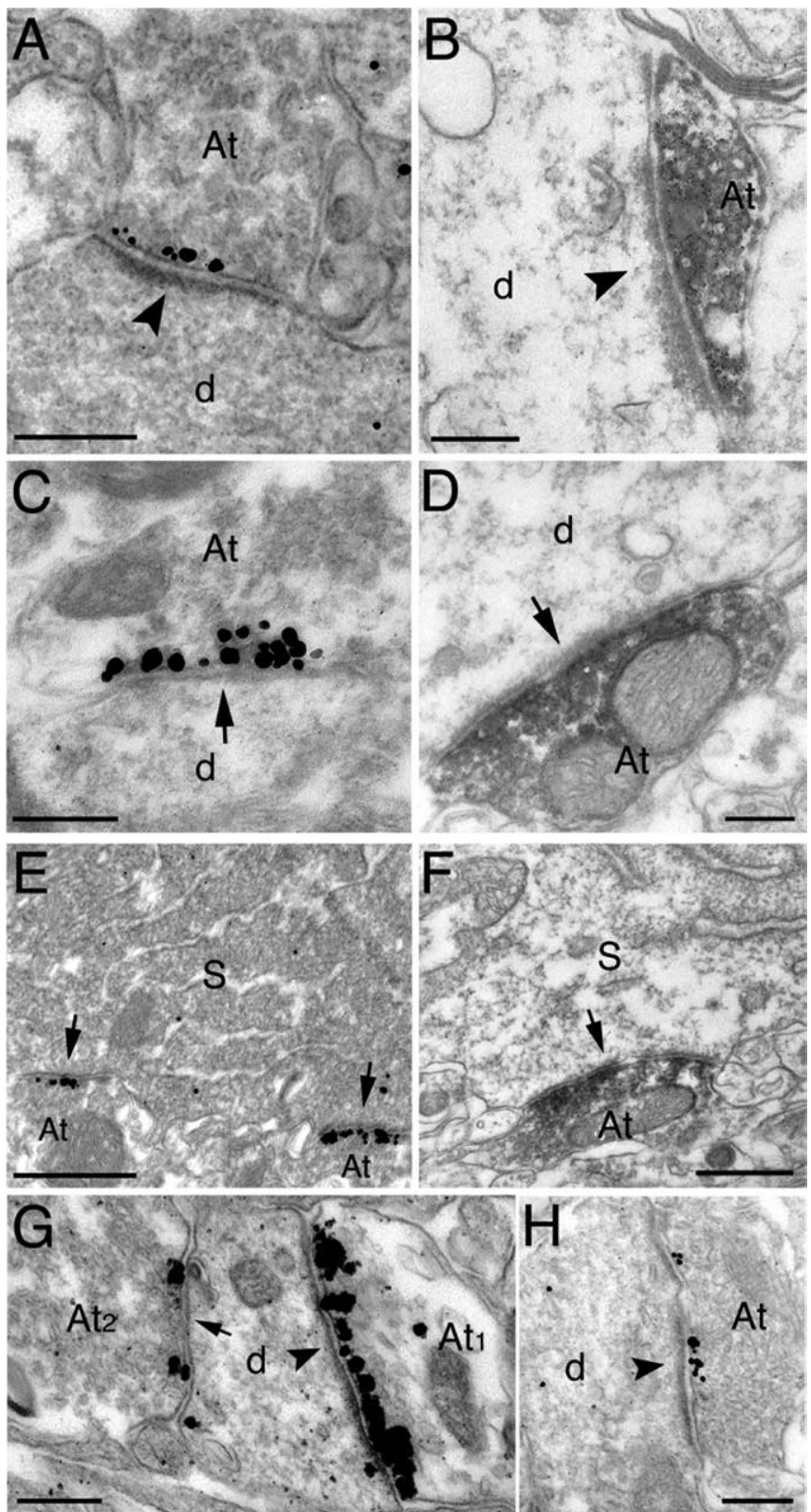

Figure 2. Electron micrographs showing immunoreactivity for mGluR8a and $m G l u R 8 b$ in the stratum oriens $(\boldsymbol{A}-\boldsymbol{G})$ and stratum lacunosum moleculare $(\boldsymbol{H})$ of the $\mathrm{CA} 1$ area. $\boldsymbol{A}, \boldsymbol{C}$, Immunogold/silver labeling for mGluR8a is concentrated in the presynaptic active zone facing the postsynaptic membrane specialization of type I (arrowhead; $\boldsymbol{A}$ ) or type II (arrow; $\boldsymbol{C}$ ) synapses on dendritic shafts. $\boldsymbol{B}, \boldsymbol{D}$, Immunoperoxidase labeling for mGluR8b spreads from the presynaptic membrane specialization in boutons forming a type I (arrowhead; $\boldsymbol{B}$ ) or a type II (arrow; $\boldsymbol{D}$ ) synapse on dendritic shafts. $\boldsymbol{E}$, Two axon terminals forming type Il synapses (arrows) with the perikaryon of a presumed interneuron show intense immunolabeling for mGluR8a. $\boldsymbol{F}$, The soma of a presumed interneuron receives a type ll synapse (arrow) from an axon terminal labeled with peroxidase immunoreaction product for mGluR8b. G, A rare example of an interneuron dendrite receiving both a type I (arrowhead) and a type II (arrow) synapse immunolabeled for mGluR8a. The density of immunoparticles is much higher in the terminals forming the type I synapse. $\boldsymbol{H}$, The presynaptic active zone of a bouton making a type I synapse (arrowhead) with a dendritic shaft in the stratum lacunosum moleculare is labeled with immunogold particles for mGluR8a. Scale bars: $\boldsymbol{A}-\boldsymbol{D}, \boldsymbol{G}, \boldsymbol{H}, 0.2 \mu \mathrm{m} ; \boldsymbol{E}, \boldsymbol{F}, 0.5 \mu \mathrm{m}$. At, Axon terminal; d, dendritic shaft; $S$, soma.

labeled terminals formed type I synapses with both dendritic shafts (Fig. $2 H$ ) and spines (data not shown). Because of the complete coexistence between the two alternatively spliced receptors, most of the experiments described below were performed only for the mGluR8a isoform, but we assume the results can be extended to mGluR8b.
The GABAergic input to CA1 interneurons originates from other local interneurons and the medial septum (Freund and Buzsaki, 1996), whereas excitatory afferents arise from a variety of intra- and extra-hippocampal sources that include CA3-CA1 pyramidal cells and projections from the entorhinal cortex, thalamus, and amygdala, respectively (Amaral and Witter, 1989; Dolleman-Van Der Weel and Witter, 1996; Pikkarainen et al., 1999). The local axon collaterals of CA1 pyramidal neurons strongly express mGluR7a, which is selectively enriched in a target cell-dependent manner (i.e., higher levels are distributed to the terminals that form synapses with SOM- and mGluRlaexpressing neurons than to terminals making synapses with pyramidal cells or other types of GABAergic neurons) (Shigemoto et al., 1996, 1997). To establish whether CA1 pyramidal cells also express mGluR8 at their axon collaterals, we labeled several pyramidal neurons with neurobiotin by the in vivo juxtacellular method (Pinault, 1996; Klausberger et al., 2003). We analyzed 201 filled boutons for the presence of mGluR8a immunoreactivity; of these, 200 did not show combined labeling, whereas for one bouton, a conclusion could not be reached because it was close to mGluR8-positive terminals. To investigate intra-hippocampal sources of mGluR8 further, we analyzed by in situ hybridization histochemistry the distribution of mGluR8 mRNA in the hippocampus. A specific signal was limited to a few scattered neurons in the stratum pyramidale and radiatum of CA fields (Fig. $4 A, B)$, dentate granule cell layer, and hilus (data not shown), which suggests a restricted expression of this receptor to some local interneurons.

The GABAergic nature of some of the mGluR8a-immunopositive terminals forming type II synapses was confirmed by double-labeling, pre-embedding experiments for electron microscopy, using immunoperoxidase (DAB) for mGluR8a to maximize sensitivity and silver-intensified immunogold for the GABA-synthesizing enzyme GAD (Fig. 4C) or the VIAAT (Fig. 4D).

These results suggest that CA1 pyramidal cells do not express mGluR8, and hence putative glutamatergic terminals containing these receptors are likely to originate from extra-hippocampal sources or CA3 pyramidal cells. Moreover, they indicate a restricted expression of mGlu8 receptors by a subset of hippocampal interneurons, which are the main candidate for the GABAergic input.

\section{Selective concentration of mGluR8 in terminals targeting oriens/alveus interneurons expressing the muscarinic acetylcholine $\mathrm{M} 2$ receptor}

To identify the interneuron populations targeted by mGluR8positive terminals, we performed double- and triple-immunofluorescence experiments combining antisera for mGluR8 and molecular markers that selectively characterize subclasses of hippocampal interneurons (Table 1). At least six different classes of the oriens/alveus interneuron with the soma and dendrites oriented horizontally have been described so far, which include oriens-lacunosum moleculare (O-LM) cells (Baude et al., 1993; McBain et al., 1994; Maccaferri et al., 2000), oriens bistratified (O-Bi) cells (Ali and Thomson, 1998; Maccaferri et al., 2000), trilaminar cells (Sik et al., 1995), muscarinic M2 acetylcholine receptor-immunoreactive interneurons (Hajos et al., 1998), and subsets of basket and axo-axonic cells (Ganter et al., 2004). These interneurons differ in axonal projections and expression of neurotransmitter receptors, calcium binding proteins, and neuropeptides.

Interneurons immunopositive for $\mathrm{M} 2$ receptors were the main, but not the only, target of mGluR8a- and mGluR8b- 
positive boutons. The density of immunoreactive terminals was high on both the soma and dendrites of these cells (Fig. 5AC). Not all M2-immunoreactive cells were outlined with mGluR8a immunofluorescent boutons (Fig. 6 C); $~ 10 \%$ of them ( 26 of 253 M2-positive cells tested in CA1) did not receive any innervation containing detectable mGluR8 labeling. To establish the type of synapses formed by mGluR8acontaining terminals, immunoreactivity for mGluR8a was demonstrated by immunoperoxidase reaction, whereas M2 receptors were demonstrated by silverintensified immunogold particles. Immunoreactivity for the M2 receptor was mainly found on the plasma membrane and concentrated perisynaptically and, to a lesser extent, on intradendritic membranes (Fig. 5D-F). Axon terminal labeling for the M2 receptor was also detected, as reported previously (Hajos et al., 1998). These terminals were primarily present in the perisomatic region of pyramidal cells, although immunopositive terminals were observed in the stratum oriens/alveus and other laminas (data not shown). Boutons immunolabeled for mGluR8a formed either type I or type II synapses on M2positive dendrites (Fig. 5D-F). Terminals displaying both M2 and mGluR8a immunoreactivity also made synapses
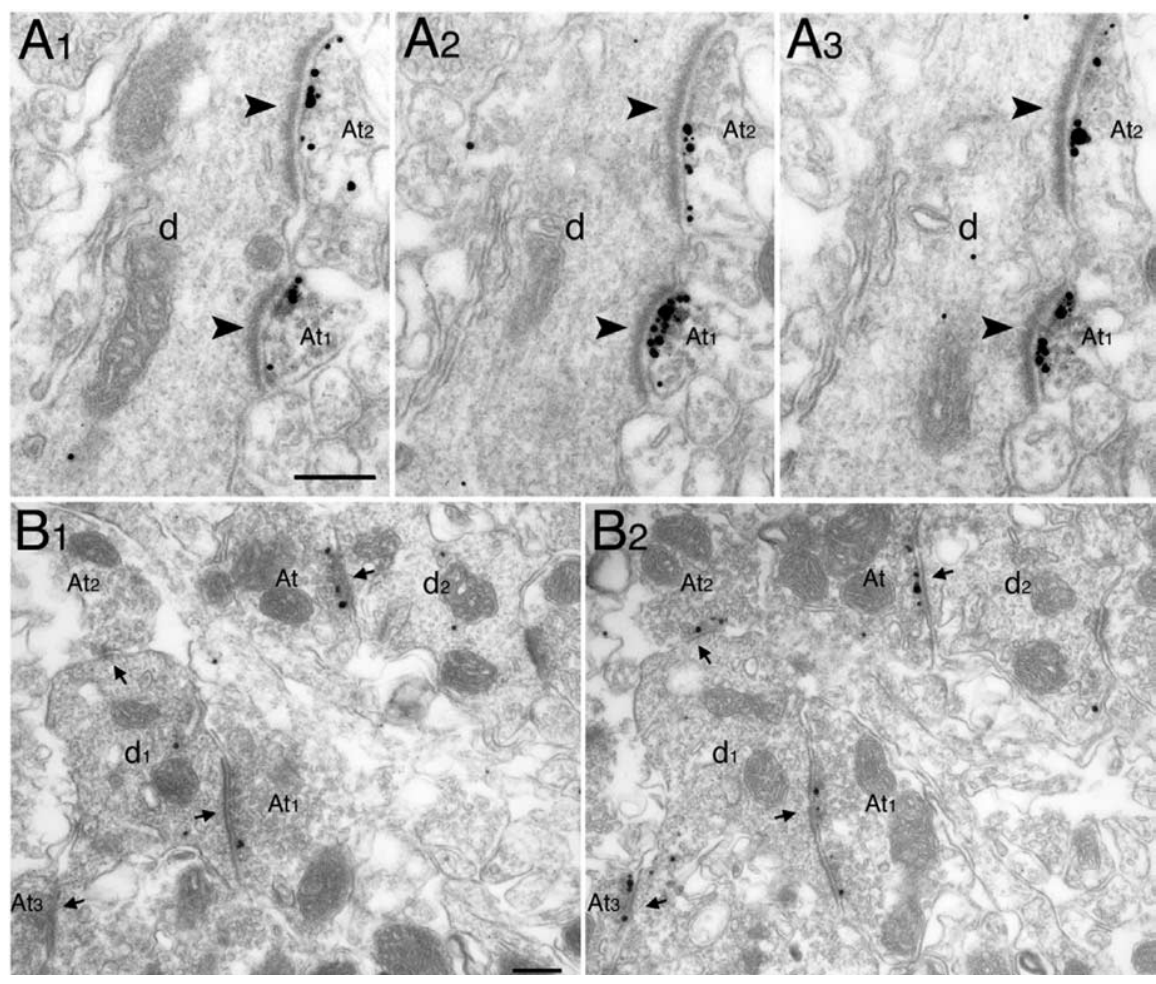

Figure 3. Electron micrographs of dendritic shafts in the CA1 stratum oriens receiving mGluR8-immunopositive boutons forming either type I or type II synapses on each dendrite. A1-A3, Consecutive sections of two mGluR8a-containing boutons (At1 and At2) establishing type I synapses (arrowheads). $\boldsymbol{B} 1-\mathbf{B 2}$, Consecutive sections of two dendritic shafts (d1 and d2) receiving mGluR8a-immunolabeled terminals forming only type II synapses (arrows). Scale bars, $0.2 \mu \mathrm{m}$. At, Axon terminal; $d$, dendritic shaft. with M2-positive dendrites (Fig. 5E).

Oriens/alveus interneurons expressing M2 receptors are a heterogeneous population containing either the neuropeptide SOM, the calcium-binding proteins $\mathrm{CR}$ or calbindin, or none of the markers distinctive for recognized interneuronal populations (Hajos et al., 1998). We performed triple-immunofluorescence experiments combining antisera for mGluR8a, M2, and SOM, $\mathrm{CR}$, or calbindin (Table 1). The vast majority of M2-positive cells immunonegative for CR, calbindin, and SOM were outlined by mGluR8a-positive terminals, yet a few did not appear to receive terminals containing mGluR8a (Fig. 6C). Rare interneurons immunoreactive for both M2 and CR (eight cells; $<5 \%$ of all M2positive cells in our sample) were consistently targeted by mGluR8a-positive axon terminals (Fig. 6A). Some of the rare M2-calbindin-positive neurons also appeared to receive mGluR8a-immunolabeled terminals (Fig. 6B). Conversely, M2and SOM-immunoreactive cells ( 6 of 43 cells sampled) comprising 14\% of M2-positive cells, consistent with that reported by Hajos et al. (1998), did not receive detectable mGluR8a-positive innervation (Fig. 6D). The overlap of M2-, calbindin-, and SOMimmunoreactive cells was not tested in the present study.

\section{mGluR8-enriched innervation of a trilaminar cell}

We attempted to determine the identity of the nonpyramidal cells, which were innervated by strongly mGluR8a-positive nerve terminals in the stratum oriens of the CA1 area. To this end, we performed juxtacellular neurobiotin labeling of in vivo recorded cells for the visualization of their processes, and immunofluorescence labeling for mGluR8a and several other molecules known to be differentially expressed in nonpyramidal cells. Of 15 neurobiotin-labeled and tested cells in the stratum oriens, one

was surrounded by strongly mGluR8a-immunopositive boutons (Fig. 7A-C). Because of the processing strategy, the soma of the cell was not tested for mGluR8a. The tested proximal dendrites were consistently followed by mGluR8a-positive dots, including the thin dendritic branches. The section containing the soma was tested for PV, CR, NK1 receptor, NPY, and SOM and was immunonegative for all of these molecules (data not shown). One section containing many dendrites of the labeled cell was reacted for mGluRla and calbindin, and the dendrites were immunonegative (data not shown). In another section, the dendrites were shown to be immunopositive for M2 receptor and sparsely contacted by mGluR7a-positive puncta (Fig. $7 D, E$ ), which probably represent immunopositive nerve terminals innervating the dendrite. After the immunoreactions, all of the sections were processed for visualization of neurobiotin by HRP reaction, and the cell was reconstructed.

The soma was located in the stratum oriens/alveus, and all of the dendrites remained in this layer including the white matter, oriented parallel with the layers (Fig. 8a). The dendritic field covered $\sim 930 \mu \mathrm{m}$ mediolaterally and $1500 \mu \mathrm{m}$ anteroposteriorly in the CA1 area and is among the largest fields in our sample of cells (Fig. 8j). The dendrites were irregularly and sparsely spiny, with most of the spines of the drumstick-shaped variety (Fig. $8 c$ ). In the CA1 area and subiculum, the axon spanned $>3.3 \mathrm{~mm}$ in the rostrocaudal direction. The axon was most dense at the level of the dendritic field and most widespread in the stratum oriens passing into the stratum pyramidale. In the vicinity of the cell, several major axon collaterals reached the border of the stratum radiatum and lacunosum moleculare, where they turned back and returned to the stratum oriens. Bouton-bearing collaterals 

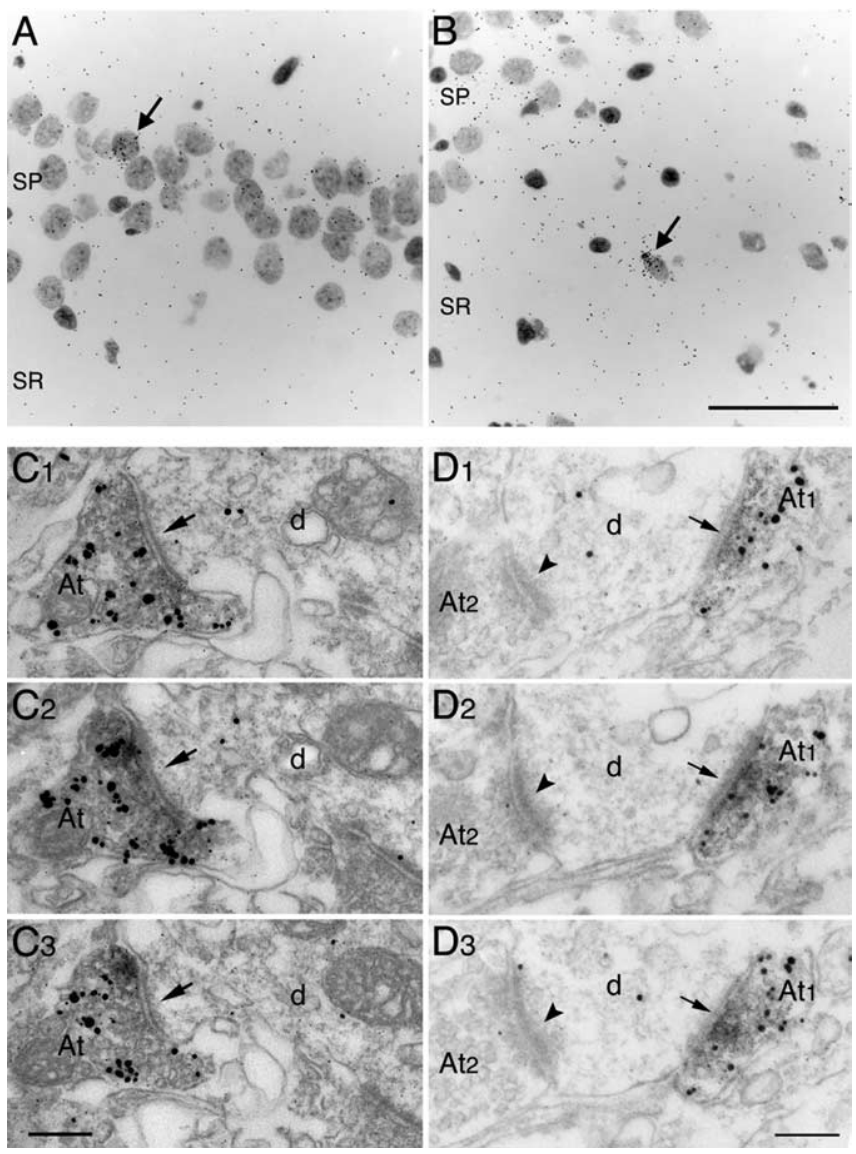

Figure 4. Localization of $m G$ luR8 $m R N A$ in the $C A 1$ area by in situ hybridization histochemistry $(\boldsymbol{A}, \boldsymbol{B})$ and colocalization of mGluR8a with GAD $(\boldsymbol{C})$ or VIAAT $(\boldsymbol{D})$ in presynaptic boutons in the CA1 stratum oriens/alveus. $A, B$, Bright-field photomicrographs of emulsion-dipped sections showing presumed interneurons (arrows), labeled for mGluR8 in the stratum pyramidale and radiatum. C1-C3, Consecutive electron micrographs of presynaptic colocalization for GAD (immunogold/silver particles) and mGluR8a (immunoperoxidase product) in an axon terminal establishing a type II synapse (arrow) with a dendritic shaft. D1-D3, Colocalization between VIAAT (immunogold/silver particles) and mGluR8a (immunoperoxidase) in serial sections of an axon terminal (At1) establishing a type Il synapse (arrow) with a dendritic shaft also receiving an immunonegative terminal (At2) forming a type I synapse (arrowhead). Scale bars: $A, B, 50$ $\mu \mathrm{m} ; C, D, 0.2 \mu \mathrm{m}$. At, Axon terminal; d, dendritic shaft; SP, stratum pyramidale; SR, stratum radiatum.

were present in all innervated layers and densest in the stratum oriens (Fig. 8d,e). Based on the orientation of the soma, the laminar distribution of the dendrites and the axon, this cell closely resembled a cell described previously in a similar position and named trilaminar cell (Sik et al., 1995). Although other properties cannot be directly compared in the two studies, we maintain this terminology here and propose that the name "trilaminar" is only applied to this specific cell type (Somogyi and Klausberger, 2005) and not to other different cells that have axons in three layers.

A surprising feature of the cell was an extensive projection to the subiculum. Three main axon branches traveled caudally in the alveus, giving short branches infrequently to the stratum oriens and pyramidale and eventually branching extensively in all layers and in a large area of the subiculum, including the molecular layer. Another collateral proceeded in the alveus/fimbria to the most-rostral pole of the hippocampus and was lost in the stratum oriens; whether it left the hippocampus could not be ascertained. In the stratum oriens and pyramidale of the CA1 area, interneurons were frequently and preferentially targeted on the somata (Fig. $8 g, h$ ) and dendrites by multiple varicosities and axonal branches. The interneurons could be identified because of their elevated level of endogenous biotin revealed by the streptavidin reaction. It appeared that only a select population of interneurons was targeted, because next to well innervated cells, others did not receive any contact from the axon. Selective innervation of nonpyramidal cells was also observed in the subiculum, but less frequently than in the CA1 area.

The cell exhibited low discharge frequencies during theta oscillations $(0.2 \mathrm{~Hz})$ (Figs. $8 b, 9 B, D)$ and non-theta/non-sharpwave episodes $(0.1 \mathrm{~Hz})$, but strongly increased its firing during sharp wave-associated ripples $(69.0 \mathrm{~Hz})$ (Fig. 9A,C). Analysis of the exact spike timing indicated that the cell fired with highest probability at the highest amplitude of the ripple episodes (Fig. $9 C)$, and at the ascending phase (122 $\pm 60^{\circ}$ after the trough) of single ripple cycles recorded in the stratum pyramidale (data not shown). During theta oscillations, the cell fired rarely but preferentially on the trough of the theta cycles recorded extracellularly in the stratum pyramidale. Unexpectedly, the interneuron fired often with a complex spike burst (Figs. 8, 9), which is evident from an increased firing probability at $2-3 \mathrm{~ms}$ in the autocorrelogram of the spike times (Fig. 9E). These $>200 \mathrm{~Hz}$ spike bursts are rather uncommon for interneurons but represent a hallmark of pyramidal cells (Ranck, 1973).

In electron-microscopic serial section analysis of neurobiotinlabeled varicosities, the synaptic specialization and the postsynaptic target could not be identified for approximately half of the varicosities studied, because the HRP end product covered the extracellular space and obscured the synapses. Identification of 79 synapses made by the axon showed that the cell mainly formed type II synapses (Fig. 9F-J). In four synapses made by the axon (two in the CA1 area, two in the subiculum), the postsynaptic density was much thicker than in the other synapses and similar in thickness to the postsynaptic densities in pyramidal cell spines. One of these synapses in the stratum radiatum and one synapse in the subiculum were made by an axon collateral, which could be shown to make conventional type II synapses at other boutons. In the CA1 area, postsynaptic targets were collected from all layers at an anteroposterior level close to the cell body ( 24 in the stratum oriens, 30 in the stratum pyramidale, 9 in the stratum radiatum) and were mainly dendritic shafts $(n=47 ; 75 \%)$ and, to a lesser extent, somata of both interneurons $(n=4 ; 6 \%)$ and pyramidal cells $(n=12 ; 19 \%)$. Postsynaptic dendritic shafts of interneurons ( $n=23$ ) were identified by receiving type I synapses (Fig. 9G,H), and they were $44 \%$ of identified postsynaptic targets. Pyramidal dendrites ( $n=13 ; 25 \%$ of identified targets) were identified by the presence of spines and/or small dense bodies (Fig. 9J) and/or originating from a pyramidal cell body. Pyramidal cell bodies ( $23 \%$ of identified targets in CA1, $19 \%$ of all targets) only received type II synapses and contained small dense bodies, whereas interneuron somata ( $8 \%$ in CA1) received both type I and type II synapses and lacked dense bodies (Fig. 9F). A significant proportion of postsynaptic dendritic shafts (18\% of targets in CA1 and $75 \%$ of all targets in the subiculum) did not display features that would have allowed the identification of the cell of origin, within the section series analyzed. In total, in the CA1 area out of the identified targets $(n=52), \sim 60 \%$ belonged to interneurons and $40 \%$ belonged to pyramidal cells. A total of 16 synapses were analyzed in the subiculum, and 4 synapses were identified as interneuron dendrites (Fig. 9H). It is likely that many of the small and medium-size unidentified dendritic shafts $(n=12)$ 

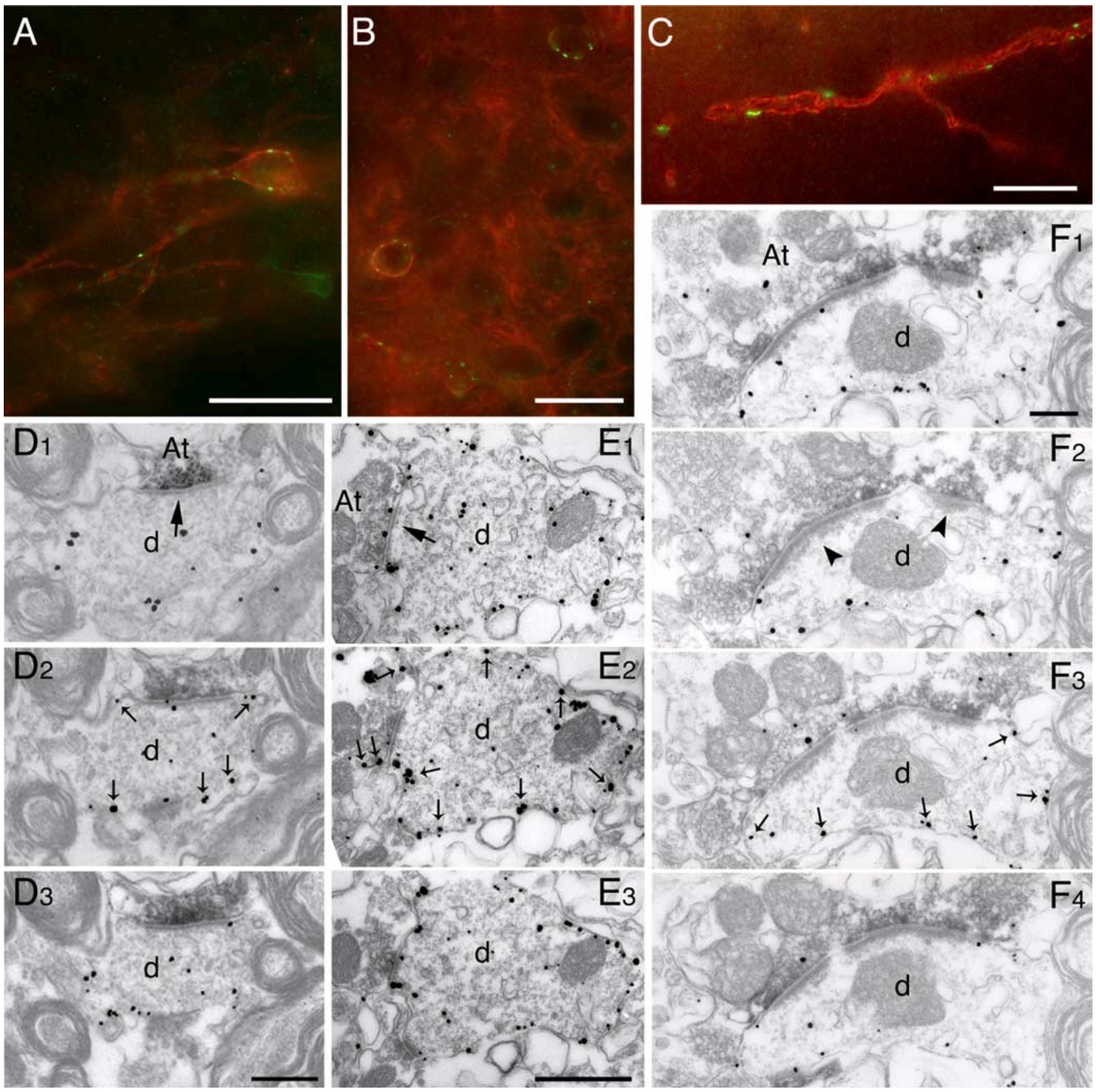

Figure 5. Specific targeting of interneurons expressing a high level of the muscarinic acetylcholine $M 2$ receptor by intensely mGluR8-immunoreactive terminals. $A-C$, Fluorescence micrographs showing interneurons immunolabeled for the M2 receptor (red) and receiving boutons immunopositive for mGluR8a or mGluR8b (green) on soma and dendrites in the CA1 stratum oriens/alveus [mGluR8a ( $\boldsymbol{A}$ ) and mGluR8b (C)] and in the CA3 stratum pyramidale (mGluR8a; $\boldsymbol{B}$ ). D1-D3, Consecutive electron micrographs showing an mGluR8a-immunoreactive (peroxidase product) bouton establishing a type II synapse (large arrow) with a M2-immunoreactive (gold/silver particles; small arrows) dendritic shaft in the CA1 stratum oriens/alveus. E1-E3, Consecutive electron micrographs showing an M2-immunoreactive (gold/silver particles; small arrows) dendritic shaft in the CA1 stratum oriens/alveus receiving a type Il synapse (large arrow) from an axon terminal immunoreactive for both mGluR8a (peroxidase labeled) and M2 (gold/silver particles) on the plasma membrane (small arrows). F1-F4, Consecutive electron micrographs showing a mGluR8aimmunoreactive (peroxidase) bouton establishing a type I perforated synapse (arrowheads) with an M2-immunoreactive (gold/silver particles on the plasma membrane; small arrows) dendritic

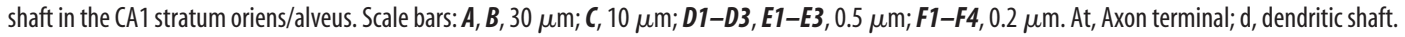

originated from pyramidal cells, but their origin could not be ascertained.

Because of the extensive axonal projection to the subiculum, which is a well known target of CA1 pyramidal cells, the infrequent type I synapses made by this cell, and the very high density of axons around the cell body, some of the axons could have originated from a pyramidal cell, the cell body of which was not labeled. Therefore, in the subiculum, we serially sec- tioned nine neurobiotin-labeled boutons of a juxtacellularly labeled CA1 pyramidal cell. All synapses made by the pyramidal cell axon were of type I with extensive postsynaptic densities, and the postsynaptic targets were dendritic spines $(n=8)$ and a dendritic shaft. Thus, both the synapse type and the targets are different from the trilaminar cell axon, excluding accidental pyramidal axon contribution to the subicular projection of this cell. 

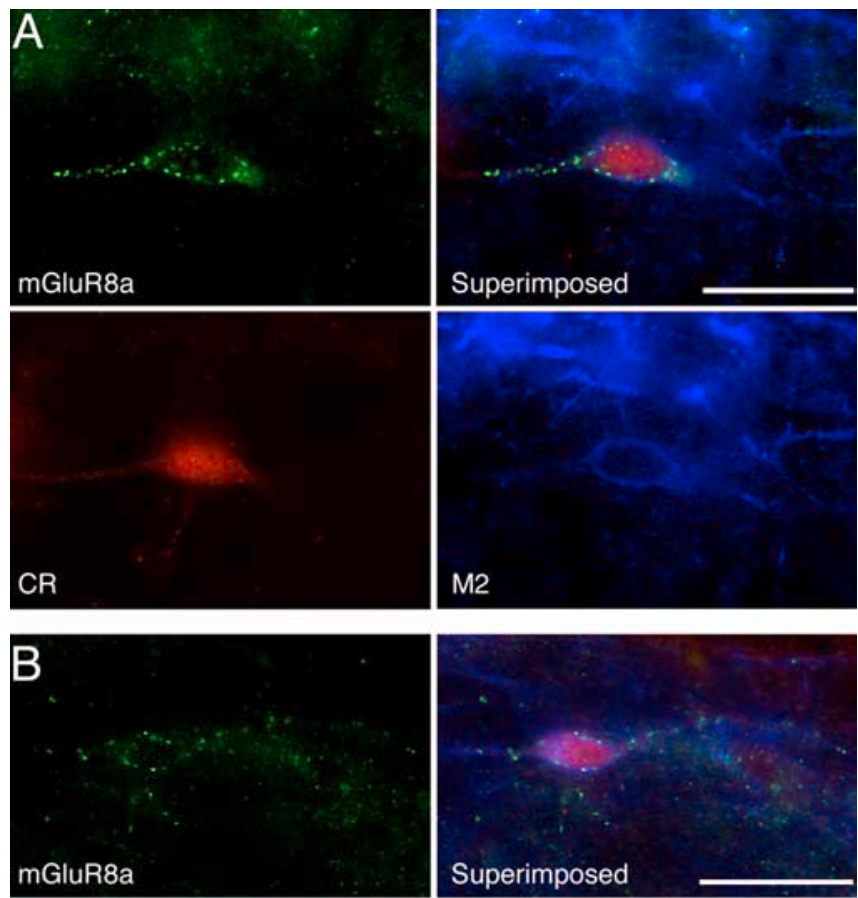

$\mathrm{M} 2$
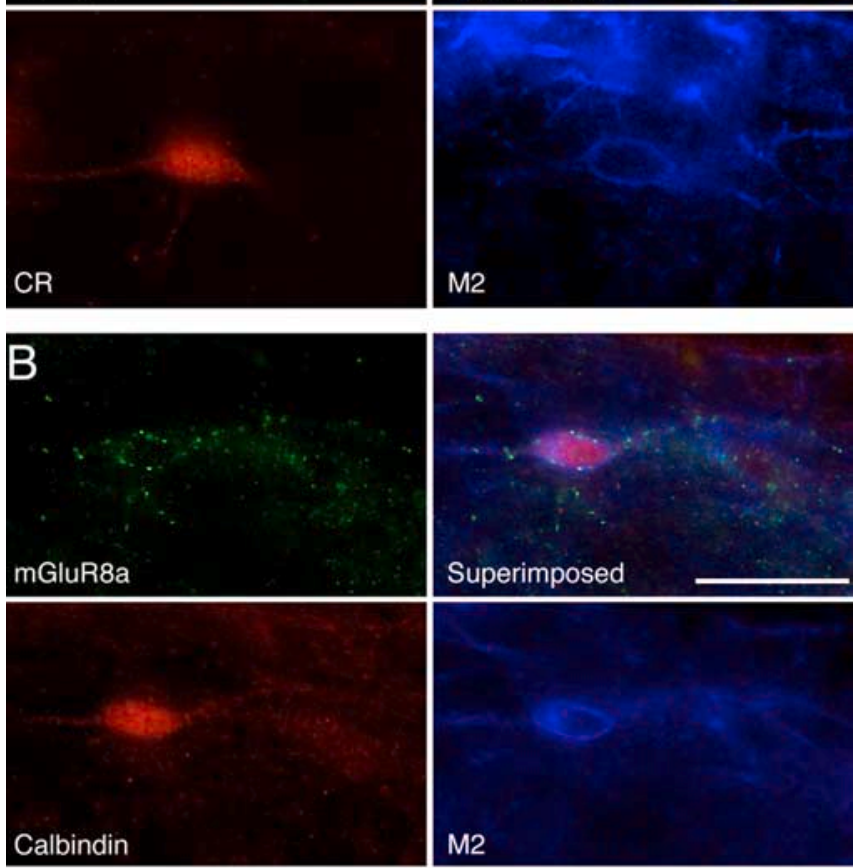

Superimposed

M2
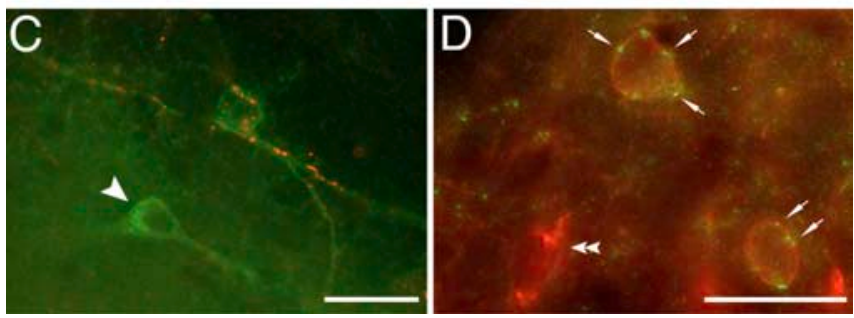

Figure 6. Interneurons decorated by mGluR8a-positive terminals and expressing M2 receptors are neurochemically heterogeneous in the CA1 stratum oriens. $A$, Immunofluorescence images taken at the same focal depth show mGluR8a-containing (green) nerve terminals around an interneuron coexpressing $M 2$ receptors (blue) and $C R$ (red). $\boldsymbol{B}$, Images showing mGluR8a-containing (green) nerve terminals surrounding an interneuron coexpressing M2 receptors (blue) and calbindin (red). The top right panels in $\boldsymbol{A}$ and $\boldsymbol{B}$ show superimposed images. C, Of two M2-immunoreactive interneurons (green), only one is decorated by mGluR8aenriched (red) terminals. $\boldsymbol{D}$, An interneuron (double arrowheads) expressing both M2 receptors in the membrane and SOM in the Golgi apparatus (both shown in red) is not innervated by mGluR8a-positive terminals (green), but two other nearby M2-immunoreactive interneurons immunonegative for SOM are richly decorated by mGluR8-positive boutons. Because the antibodies against $\mathrm{M} 2$ receptors and SOM were raised in rat and mouse, respectively, anti-mouse secondary antibodies visualized both primary antibodies. However, because of the subcellular segregation of $\mathrm{SOM}$ and $\mathrm{M} 2$ receptors, we could always differentiate between the two signals. Scale bars, $30 \mu \mathrm{m}$.

\section{mGluR1a-expressing interneurons are targeted by terminals} immunopositive for mGluR8a

Besides M2-positive cells, mGluR8a-positive terminals contacted other interneurons, although these terminals were seemingly fewer, the intensity of the immunofluorescence signal was lower, and their size appeared generally smaller. Among these interneurons, a few CR-positive (Fig. 10A) or calbindin-positive cells (Fig. $10 \mathrm{~B})$, both M2 negative, had the soma and/or dendrites deco-
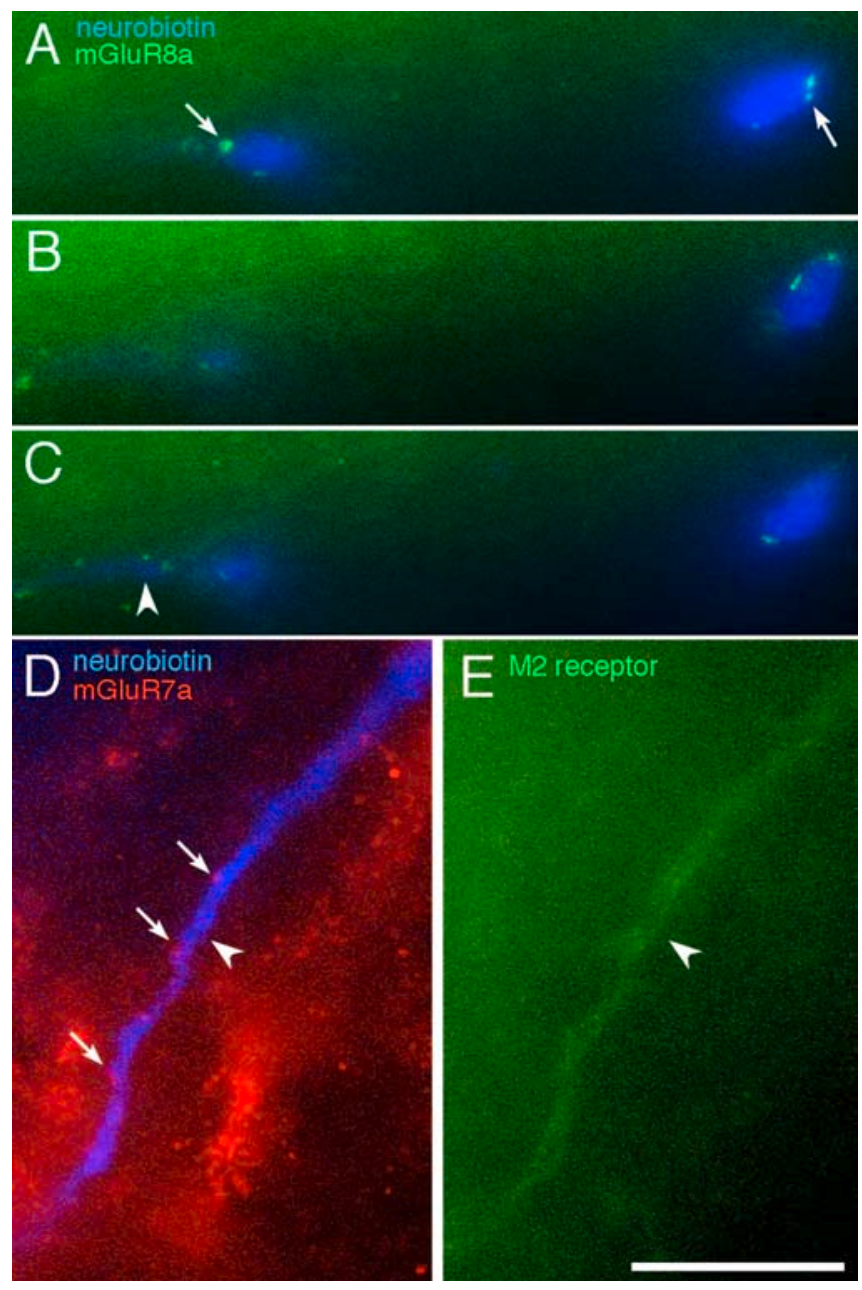

Figure 7. Neurochemical properties of a trilaminar cell as shown by immunofluorescence. A-C, Series of micrographs taken at different focal depth and showing mGluR8a-enriched boutons (green dots, arrows) innervating the dendrites identified by streptavidin-AMCA (blue) of the cell shown in Figure 8. In addition to the two large dendrites, a small dendritic branch (arrowhead; $\boldsymbol{C}$ ) is also decorated by mGluR8a-positive terminals. D, E, Triple-color fluorescence micrographs of one of the dendrites (arrowhead, streptavidin-AMCA, blue) showing a high level of $\mathrm{M} 2$ receptor immunoreactivity (green) in the membrane and innervation by $\mathrm{mGluR7a-}$ immunoreactive nerve terminals (arrows, red). Nearby dendrites, mainly originating from 0-LM cells, which are immunonegative for $\mathrm{M} 2$ receptor, are more densely surrounded by strongly mGluR7a-positive terminals. Scale bar, $10 \mu \mathrm{m}$.

rated with mGluR8a-positive terminals. In addition, a small population $(17 \%$; 21 of 147 tested in CA1) of CCK-positive cells received mGluR8a-immunolabeled boutons onto their dendrites and, to a lesser extent, on the soma (Fig. 10C). For the majority of CCK-containing neurons, no mGluR8a-positive terminals could be detected on either the dendrites or the soma. The distribution of the somata of the two groups was not different.

However, the most significant fraction of M2-immunonegative interneurons decorated by mGluR8a-containing terminals was found to express mGluRla (Fig. 11). These were most clearly and frequently observed in the subiculum and in the immediately adjacent stratum oriens of the CA1 area. More laterally in the dorsal hippocampus, mGluR1a-positive neurons were only rarely apposed by mGluR8-labeled boutons. These cells were scattered in both the stratum oriens and pyramidale, but sometimes they could also be seen in the radiatum (data not shown). Interneurons expressing mGluR1a, similarly to M2-containing interneurons, were recently shown to belong to different cell 
classes, which include O-LM cells, O-Bi cells, and interneurons selectively targeting other interneurons (IS) (Losonczy et al., 2002; Ferraguti et al., 2004). Because O-LM cells are known to express high levels of postsynaptic mGluRla receptors (Baude et al., 1993), to contain both SOM and PV (Klausberger et al., 2003; Ferraguti et al., 2004) and also to be heavily decorated by mGluR7a-containing terminals (Shigemoto et al., 1996, 1997), we performed a series of triple-immunolabeling experiments combining antisera for these markers (Table 1). Terminals containing mGluR8a immunoreactivity unevenly innervated mGluRla-immunolabeled neurons expressing SOM as well as PV (Fig. $11 A, B)$. These were frequently observed in the subiculum but not elsewhere. Neurons intensely immunolabeled for PV, but not for mGluRla, were never decorated by mGluR8a-positive terminals (Fig. 11B). The vast majority of SOM-positive neurons in the stratum oriens/alveus were richly innervated by mGluR7aimmunopositive terminals, but only a few of them, with the exception of the subiculum, appeared outlined by mGluR8aimmunopositive terminals. However, several oriens/alveus interneurons immunonegative for SOM were seen decorated by terminals labeled for mGluR7a and mGluR8. In some cases, the labeling for the two receptors appeared colocalized in the same terminal (Fig. 12A).

Double-immunocytochemical experiments for electron microscopy were performed to elucidate the type of synapses formed by mGluR8a-containing terminals onto mGluRla-immunoreactive interneurons. Immunoreactivity for mGluR8a was demonstrated by immunoperoxidase reaction, whereas the one for mGluRla was shown by silver-intensified immunogold particles. Immunoreactivity for mGluR1a was mainly found on the plasma membrane and concentrated perisynaptically. Terminals immunolabeled for mGluR8a formed either type I (Fig. 11E) or type II (Fig. 11D) synapses on mGluR1a-positive dendrites.

We also investigated by immunofluorescence whether interneurons displaying immunoreactivity for mGluRla and receiving mGluR8a-positive terminals also contained CR and/or VIP, because mGluR7a is strongly expressed in VIPpositive GABAergic boutons (Somogyi et al., 2003). In the CA1 and CA3 stratum pyramidale and radiatum, sporadic interneurons decorated by mGluR8a-enriched boutons and coexpressing mGluR1a and CR could be observed (Fig. 12B). In addition, terminals in the stratum oriens/alveus contained both mGluR8a and VIP (Fig. 12C).

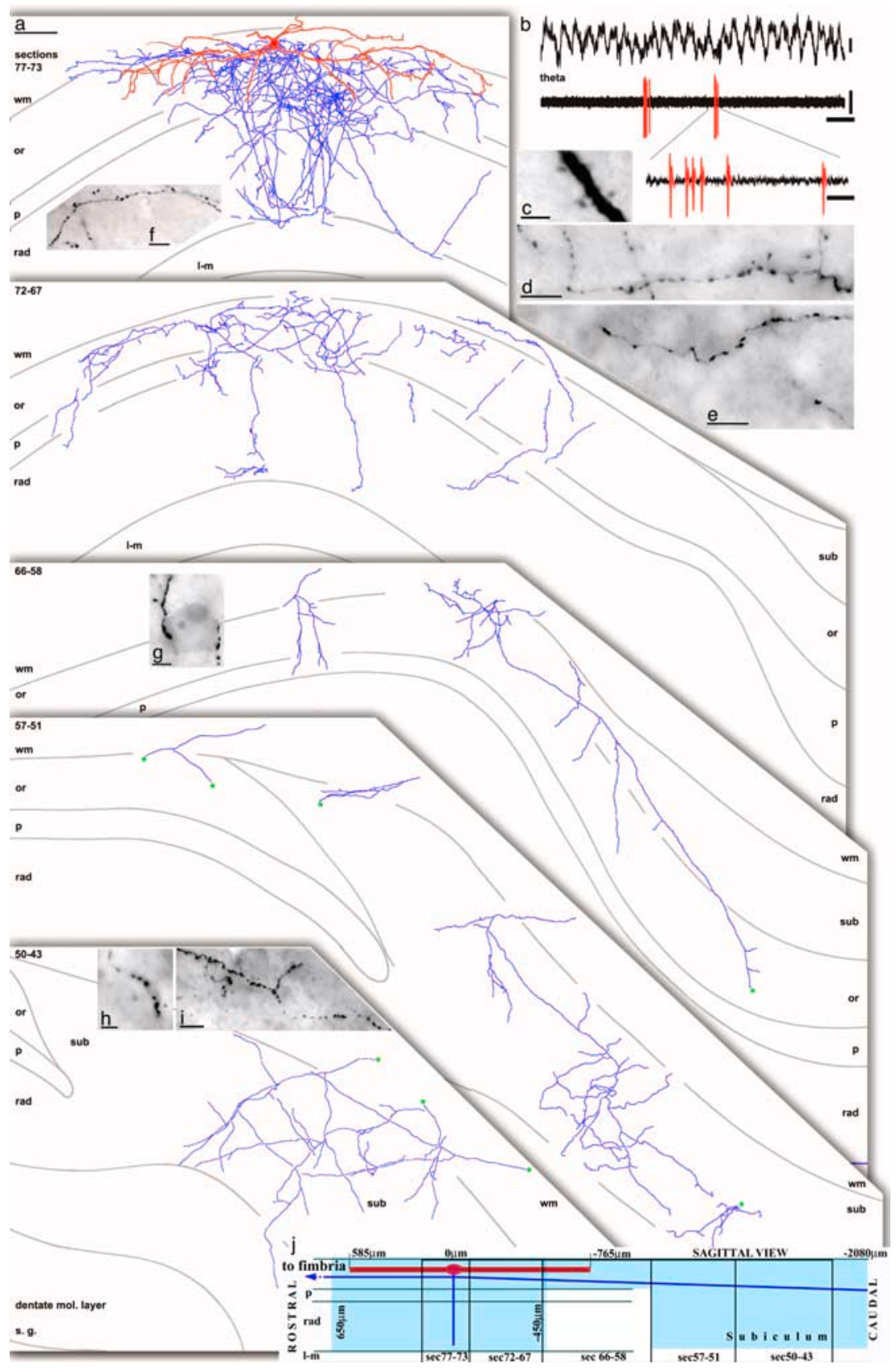

Figure 8. Dendritic, axonal, and firing patterns of a trilaminar cell (T85a) recorded in vivo and innervated by mGluR8a-enriched boutons in the CA1 area. $\boldsymbol{a}$, Reconstruction of the cell with soma in the stratum oriens/alveus. The numbers in the top left corner indicate section numbers (65 $\mu \mathrm{m}$ thickness) collapsed into two-dimensional views of the axon. The dendrites (in red) mostly remain in the stratum oriens and close to the white matter and are collapsed into the top panel from six sections (72-77); the remainder of dendrites oriented perpendicular to the section plane are not shown in the other panels, for clarity. The axon (in light blue) spread through all layers, except the stratum lacunosum moleculare, and was most dense and widespread in the stratum oriens. Three main axon branches traveled caudally and branched extensively in all layers of the subiculum. Asterisks (in green) mark continuation points of the axon in the subiculum. One axon collateral proceeded anterior in the white matter (data not shown) and was lost in the most-anterior hippocampus. $\boldsymbol{b}$, During theta activity, the cell rarely fired, but when it did, it fired in bursts. $\boldsymbol{c}$, The dendrites were sparsely spiny. $\boldsymbol{d}-\boldsymbol{i}$, Boutons were present at high density along axon collaterals in the stratum oriens (d), stratum pyramidale $(\boldsymbol{e})$, stratum radiatum $(\boldsymbol{f})$, and in the subiculum (i). Both in the CA1 area and the subiculum, some axonal branches innervated nonpyramidal cells on their soma $(\boldsymbol{g}, \boldsymbol{h})$ and dendrites via multiple varicosities. Scale bars: $\boldsymbol{a}, 100 \mu \mathrm{m} ; \boldsymbol{c}, 2.5$ $\mu \mathrm{m} ; \boldsymbol{d}-\boldsymbol{f}, \boldsymbol{i}, 10 \mu \mathrm{m} ; \boldsymbol{g}, \boldsymbol{h}, 5 \mu \mathrm{m}$. Calibration: $\boldsymbol{b}, 0.2 \mathrm{mV}, 500 \mathrm{~ms}$; inset, $10 \mathrm{~ms}$. wm, White matter; or, stratum oriens; P, stratum pyramidale; rad, stratum radiatum; I-m, stratum lacunosum moleculare; sub, subiculum; mol., molecular.

\section{Discussion}

A striking innervation of GABAergic neurons by mGluR8expressing presumed glutamatergic and GABAergic boutons has been revealed in the hippocampus, in addition to the lateral per- 

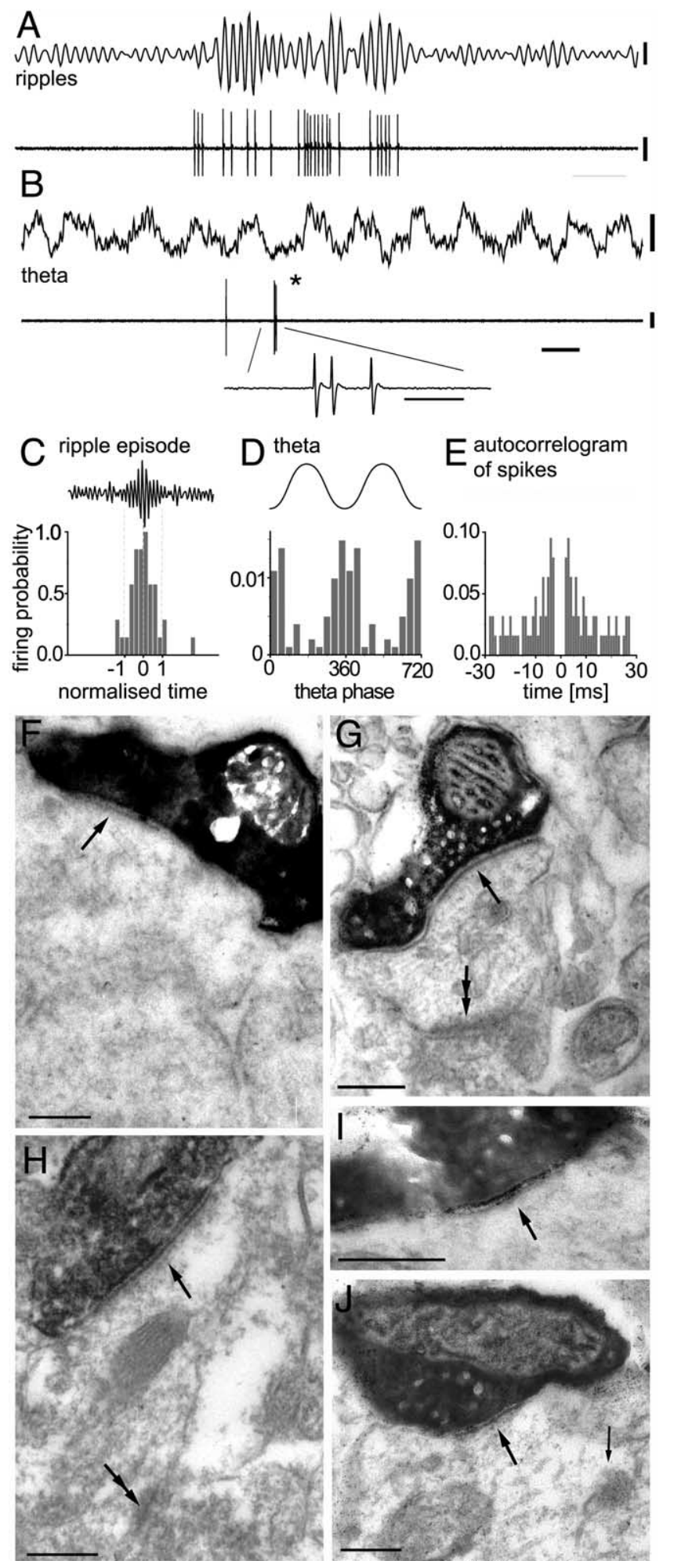

Figure 9. Firing patterns and synaptic targets of the trilaminar cell. $\boldsymbol{A}$, The cell fired (bottom trace) at high frequency during sharp wave-associated ripple episodes (filtered $90-140 \mathrm{~Hz}$; top trace). $\boldsymbol{B}$, During theta oscillations, the cell fired only occasionally but often with a complex spike burst $\left.{ }^{*}\right)$. C, The firing probability was greatest at the highest amplitude of the ripple episodes. The start, highest amplitude, and end of the normalized ripple episodes are marked as $-1,0$, and 1 , respectively. $\boldsymbol{D}$, The cell fired preferentially at the trough of the theta oscillations. For clarity, the same data are repeated in two theta cycles, in which $0^{\circ}$ and $360^{\circ}$ mark the troughs of the extracellularly recorded field potential oscillation. $\boldsymbol{E}$, The autocorrelogram of spike times during theta oscillations shows that the firing probability is increased 2-3 ms after/before a spike. $\boldsymbol{F}-\boldsymbol{J}$, Synaptic targets of neurobiotin-labeled boutons visualized by peroxidase reaction. $\boldsymbol{F}$, Synapse (arrow) on an interneuron soma in the stratum pyramidale. $\mathbf{G}, \boldsymbol{H}$, Synapses (arrows) forant path innervation of the dentate gyrus reported previously (Shigemoto et al., 1997). Like other group III mGluRs, mGluR8 is selectively located in the presynaptic active zone of both GABAergic and glutamatergic terminals. We revealed the firing pattern of one of the major mGluR8 recipient neurons, the trilaminar cell that heavily innervates the subiculum in addition to the CA1 area. We also provide the first account for the immunolocalization of the other full-length alternatively spliced receptor isoform, mGluR8b (Corti et al., 1998).

\section{Distribution and subcellular location of group III mGluRs}

The presence of mRNA for mGluR8 in the hippocampus was demonstrated by reverse transcription-PCR (Corti et al., 1998), but in situ hybridization either did not produce a detectable signal (Duvoisin et al., 1995; Corti et al., 1998) or showed widespread expression including CA1-CA3 pyramidal cells (Saugstad et al., 1997; Messenger et al., 2002). We detected a weak but specific signal only in a few interneurons. Hence, the GAD- and mGluR8-immunopositive terminals are likely to originate from these interneurons. The previous negative results may be attributed to a lower sensitivity of the procedures. Conversely, the reported signal in pyramidal neurons could be nonspecific labeling. Because of the intrinsic detection limit, we cannot rule out expression of mGluR8 by pyramidal cells, particularly in CA3. However, based on the overall evidence, we assume that mGluR8-containing glutamatergic inputs originate primarily from an extra-hippocampal source(s), like the entorhinal cortex, amygdala, and thalamus (Amaral and Witter, 1989; DollemanVan Der Weel and Witter, 1996; Pikkarainen et al., 1999). The former two areas express relatively high levels of mGluR8 transcripts (Corti et al., 1998), unlike the projection nuclei of the thalamus (Saugstad et al., 1997; Corti et al., 1998; Messenger et al., 2002).

The high concentration of mGluR8 in the input to specific interneuron classes was also observed for other group III receptors, such as mGluR7a (Bradley et al., 1996; Shigemoto et al., 1996, 1997), mGluR7b (Somogyi et al., 2003), and mGluR4 (Corti et al., 2002). A target cell-specific enrichment of mGluR7a was found in pyramidal cell axons innervating O-LM interneurons versus pyramidal cells (Shigemoto et al., 1996, 1997; Somogyi et al., 2003). A target cell-specific enrichment of mGluR8 is suggested by the depression by L-2-amino-4phosphonobutyric acid (L-AP-4) of glutamatergic transmission to GABAergic neurons but not to pyramidal cells at a concentration compatible with the activation of mGluR8 (or mGluR4), but not of mGluR7 (Scanziani et al., 1998). Although it is not known whether GABAergic neurons also express presynaptic group III mGluRs according to distinct targets along single axons, our previous and current findings are suggestive of some postsynaptic influence also onto inhibitory axon terminals.

We found that the immunoreactivity for the two isoforms was entirely overlapping not only in the hippocampal formation but also in other telencephalic areas such as the piriform cortex, neocortex, amygdala, and globus pallidus (data not shown). Thiscorresponding distribution, together with their analogous intracel-

on small interneuron dendrites identified by an additional nearby type I synapse (double arrows) in the stratum oriens $(\boldsymbol{G})$ and the subiculum $(\boldsymbol{H})$. $\boldsymbol{I}, \boldsymbol{J}$, Synapses (arrows) received by the soma $(\boldsymbol{I})$ and main apical dendrite $(\boldsymbol{J})$ of pyramidal cells in the CA1 area. The pyramidal cell dendrite is identified by the presence of small dense bodies (small vertical arrow). The peroxidase product spread into the synaptic cleft in I. Calibration: $A$, ripples, $0.05 \mathrm{mV}$; spikes, $0.5 \mathrm{mV}$, $50 \mathrm{~ms} ; \boldsymbol{B}$, theta and spikes, $0.5 \mathrm{mV}, 200 \mathrm{~ms}$; inset, $10 \mathrm{~ms}$. Scale bars: $\boldsymbol{F}-\boldsymbol{J}, 0.2 \mu \mathrm{m}$. 

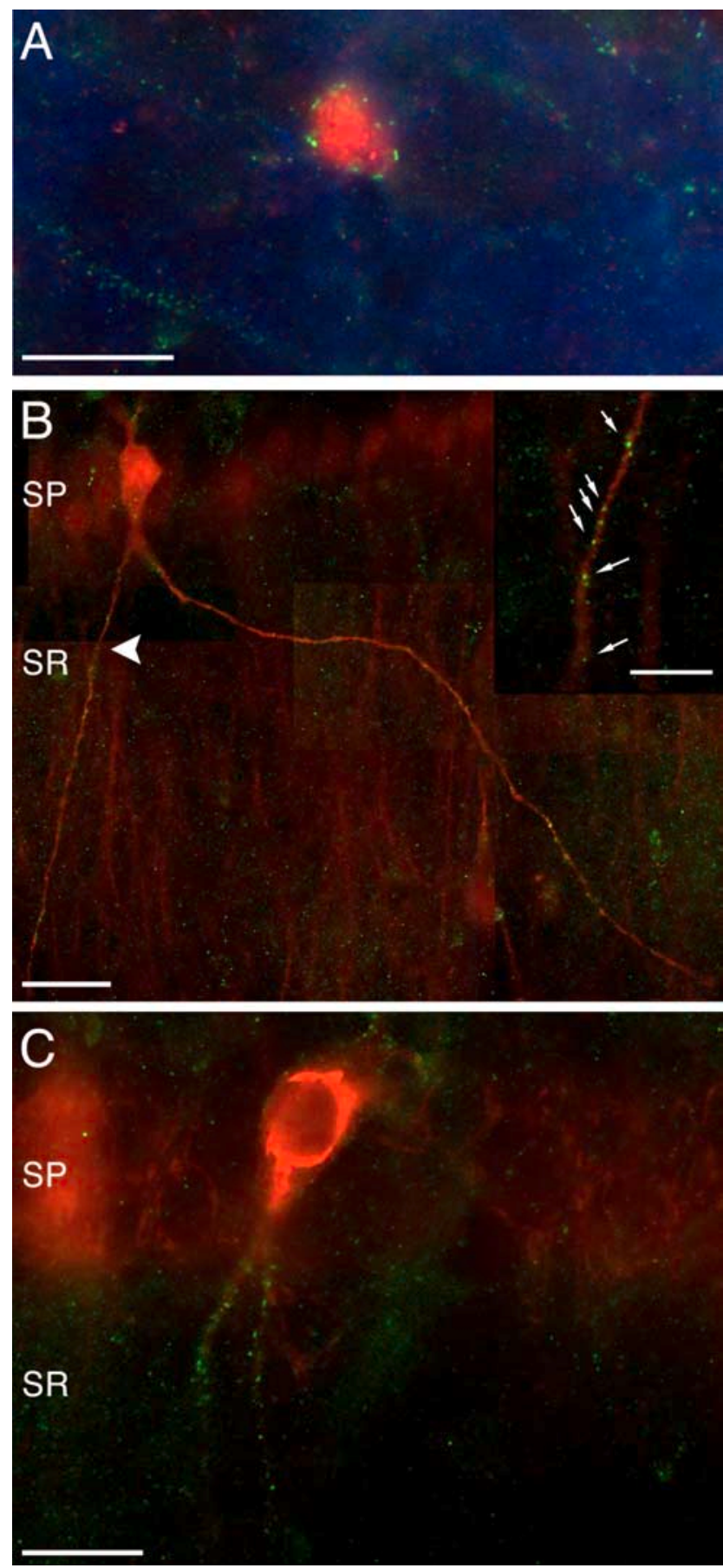

Figure 10. Interneurons in the CA1 area expressing CCK or the calcium-binding proteins CR or calbindin but immunonegative for the M2 receptor, are decorated by mGluR8a-enriched nerve terminals. A, Immunofluorescence superimposed images showing the soma of a CRimmunopositive (red) neuron in the stratum oriens that is targeted by mGluR8a-enriched terminals (green) but showed no M2 immunoreactivity (blue). $\boldsymbol{B}$, A calbindin-expressing (red) interneuron in the stratum pyramidale receives a dense innervation by mGluR8a-positive (green) boutons mainly on the dendrites in the stratum radiatum. Inset, Higher-magnification portion of a dendrite (arrowhead) contacted by labeled small boutons (arrows). C, A CCKexpressing (red) interneuron in the stratum pyramidale is innervated mainly on its dendrites in the stratum radiatum by mGluR8a-containing (green) boutons. Scale bars: $A, B, 30 \mu \mathrm{m}$; inset, $10 \mu \mathrm{m} ; C, 30 \mu \mathrm{m}$. SP, Stratum pyramidale; SR, stratum radiatum.

lular coupling properties and pharmacological profile (Corti et al., 1998; Malherbe et al., 1999), suggests a heterodimerization of the two isoforms.

\section{Selective expression of $\mathrm{mGluR8}$ in relation to specific} cell types

The most prominent targets of mGluR8-positive synapses are the horizontal M2 receptor-immunoreactive neurons in the CA1 oriens/alveus and in the CA3 area. The mGluR8 decoration of these cells is both denser and stronger than that of other cell types. The visualization of the axon and dendrites of one of these cells made it possible to identify them as the trilaminar cells (Sik et al., 1995). The firing of complex spike bursts together with the axonal distribution, synapses onto pyramidal cell somata and onto a high proportion of interneurons, and their septal projection clearly separate this cell type from other interneurons (Somogyi and Klausberger, 2005). Trilaminar cells are the fourth independent identified source of GABA onto pyramidal cell somata (Somogyi and Klausberger, 2005). The preferential targeting of other interneurons by trilaminar cells, together with their highfrequency firing on sharp wave-associated ripples, points to the possibility that this cell might contribute to the specific silencing of axo-axonic or O-LM cells (Klausberger et al., 2003), which are inhibited during ripple episodes. Because O-LM cells are mostly in the alveus/oriens, whereas the trilaminar cell targets were in and around the pyramidal cell layer, axo-axonic cells are the most likely candidates.

The source of excitatory drive to trilaminar cells is not known. During theta activity, the prolonged glutamate release from all hippocampal afferents would increase ambient glutamate levels and activate mGluR8, leading to suppression of glutamate release to trilaminar cells and hence contributing to their low firing rate. During slow wave sleep and related brain states, the episodic firing of pyramidal cells interspersed with long periods of low activity would only increase glutamate levels during ripples, allowing the trilaminar cells to be activated by glutamatergic afferents, followed by mGluR8-mediated suppression. The firing of trilaminar cells during ripples is in concert with basket and bistratified cells, all innervating the pyramidal cell soma. During theta activity, trilaminar cells would fire out of phase with basket cells, but their low firing rate may not significantly contribute to perisomatic pyramidal cell inhibition.

Both the density of terminals and the amount of mGluR8 were distinctively lower in the input to other interneuron types compared with M2 receptor-positive cells. Interneurons receiving mGluR8 innervation and positive for mGluR1a, SOM, and weakly for PV are probably O-LM cells (Shigemoto et al., 1996; Klausberger et al., 2003; Ferraguti et al., 2004). A few other mGluR8-decorated cells contained CR and may be IS (Freund and Buzsaki, 1996; Ferraguti et al., 2004). The rare calbindin- or CCK-positive neurons innervated by mGluR8 terminals may belong to the Schaffer collateral-associated interneurons expressing both CCK and calbindin (Cope et al., 2002). The unambiguous identification of these cells awaits visualization of their axonal patterns.

The electron-microscopic analysis suggested that mGluR8expressing GABAergic and glutamatergic terminals target mainly separate postsynaptic cell types, possibly corresponding to specific subtypes of M2- and mGluR1a-positive interneurons. The coexpression of VIP and mGluR8 or mGluR7a and mGluR8a in a subset of terminals suggests that O-LM-like cells are their targets, because O-LM cells receive strong GABAergic innervation from $\mathrm{VIP} / \mathrm{mGluR7a-positive} \mathrm{terminals} \mathrm{of} \mathrm{IS-III} \mathrm{cells} \mathrm{(Blasco-Ibanez}$ and Freund, 1995; Somogyi et al., 2003). An exception to the segregation of GABAergic and glutamatergic inputs might be the subclass of M2- and CR-positive interneurons (Freund and Buzsaki, 1996) decorated by both mGluR7a- and mGluR8- 

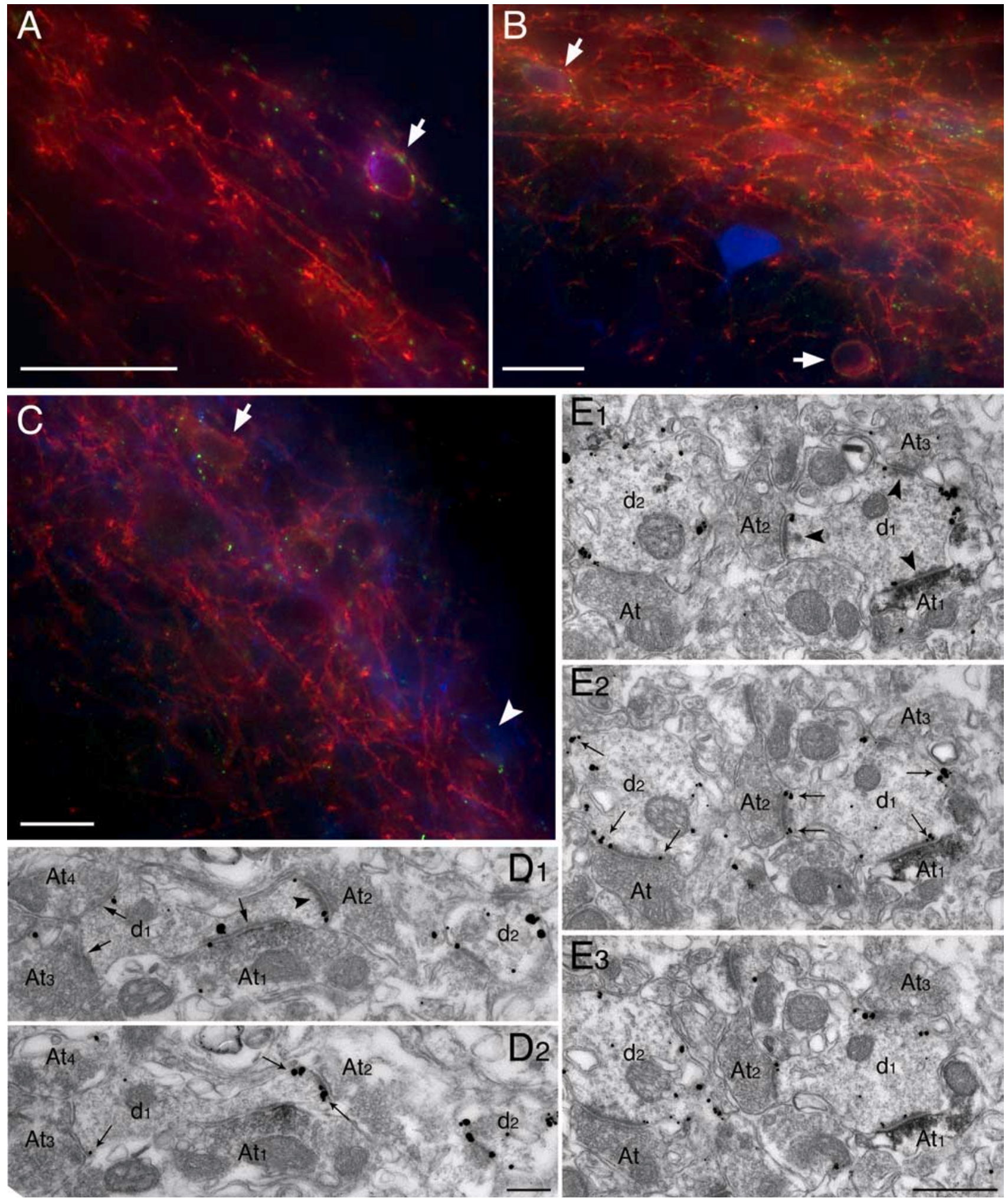

Figure 11. Some terminals immunoreactive for mGluR8a target interneurons expressing mGluR1a in the stratum oriens/alveus. $A$, Fluorescence micrograph of triple-immunolabeling for mGluR1a (red), SOM (blue), and mGluR8a (green) showing an interneuron (arrow) that is positive for mGluR1a in the plasma membrane, positive for SOM in the Golgi apparatus, and decorated by mGluR8a-immunopositive puncta. $\boldsymbol{B}$, In this triple-fluorescence immunolabeling for mGluR1a (red), PV (blue), and mGluR8a (green), two interneurons (arrows) immunopositive for mGluR1a and weakly positive for $\mathrm{PV}$ are decorated by $\mathrm{mGluR8a-containing} \mathrm{terminals.} \mathrm{The} \mathrm{interneuron} \mathrm{strongly} \mathrm{labeled} \mathrm{for} \mathrm{PV} \mathrm{and} \mathrm{immunonegative} \mathrm{for} \mathrm{mGluR1a} \mathrm{does} \mathrm{not} \mathrm{receive} \mathrm{detectable} \mathrm{mGluR8a} \mathrm{innervation.}$ C, Triple-immunolabeling for mGluR1a (red), muscarinic M2 receptor (blue) and mGluR8a (green). No coexistence between mGluR1a and M2 receptors could be detected. Terminals immunopositive for mGluR8a decorate dendrites immunolabeled either for mGluR1a (arrow) or M2 (arrowhead). D1, D2, Consecutive electron micrographs showing an mGluR8a-immunoreactive (peroxidase product) bouton (At1) establishing a type Il synaptic contact (large arrow) on the neck of a dendritic spine immunoreactive for mGluR1a (gold/silver particles) (small arrows; D2). The dendritic shaft receives two additional immunonegative boutons (At3, At4) also establishing type ll synapses (large arrows; D1).E1-E3, Interneuron dendrites, immunoreactive for mGluR1a (gold/silver particles; small arrows) are shown in consecutive electron micrographs. Dendrite d1 receives an mGluR8a-positive (peroxidase product) axon terminal (At1), which along with two other immunonegative boutons (At2, At3) establishes a type I synaptic junction (arrowheads). At, Axon terminal; d, dendritic shaft. Scale bars: A-C, $30 \mu \mathrm{m} ; \mathbf{D 1}, \mathbf{D 2}, 0.2 \mu \mathrm{m} ; \mathbf{E 1}-\mathbf{E 3}, 0.5 \mu \mathrm{m}$. 
enriched terminals, possibly representing a subclass of IS interneurons. Cauli et al. (2000) reported that among fusiform neocortical interneurons, those displaying irregular spiking and containing transcripts for VIP and/or CR also frequently coexpressed mGluR8 and may be homologous to hippocampal IS interneurons (Acsady et al., 1996).

\section{The role of group III mGluRs}

In the presynaptic active zone of glutamatergic boutons, mGluR8 is probably an autoreceptor regulating glutamate release (Baskys and Malenka, 1991; Desai et al., 1994; Gereau and Conn, 1995; Scanziani et al., 1998), whereas in GABAergic terminals, it may regulate heterosynaptically GABA release (Gereau and Conn, 1995; Poncer et al., 1995; Morishita et al., 1998; Semyanov and Kullmann, 2000; Kogo et al., 2004). We have shown recently that at $50 \mu \mathrm{M}$ L-AP-4 depressed IPSCs in oriens/ alveus interneurons, including identified O-LM cells (Kogo et al., 2004), consistent with the activation of mGluR8 (Wu et al., 1998; Schoepp et al., 1999; Rosemond et al., 2002). In pyramidal cells, IPSC depression was observed only at concentrations $\geq 300 \mu \mathrm{M}$ (Morishita et al., 1998; Semyanov and Kullmann, 2000; Kogo et al., 2004), suggestive of a preferential action on the low-affinity mGlu7 receptors (Wu et al., 1998; Schoepp et al., 1999; Rosemond et al., 2002). Furthermore, the variable depression of IPSCs in interneurons (Kogo et al., 2004) indicated heterogeneity of GABAergic inputs containing a different complement of group III mGluRs. Glutamatergic inputs to interneurons are also suppressed by group III mGluR activation (Scanziani et al., 1998; Semyanov and Kullmann, 2000; Losonczy et al., 2002). The selective distribution of group III mGluRs in GABA terminals may underlie inputspecific, frequency, and/or time-dependent regulation of hippocampal circuits.

Targeted deletion of the mGluR8 gene in mice produces subtle behavioral alterations such as reduced habituation to novelty, hyperactivity, context-dependent but not cue-dependent disruption of the freezing response in the fear conditioning test (Gerlai et al., 2002), and increased anxiety (Linden et al., 2002). These alterations point to an abnormal hippocampal function that, besides a reduced presynaptic control of glutamate release from the lateral perforant path onto granule cells (Bushell et al., 1996; Shigemoto et al., 1997; Zhai et al., 2002), will also result in altered temporal patterns of GABA release from interneurons.
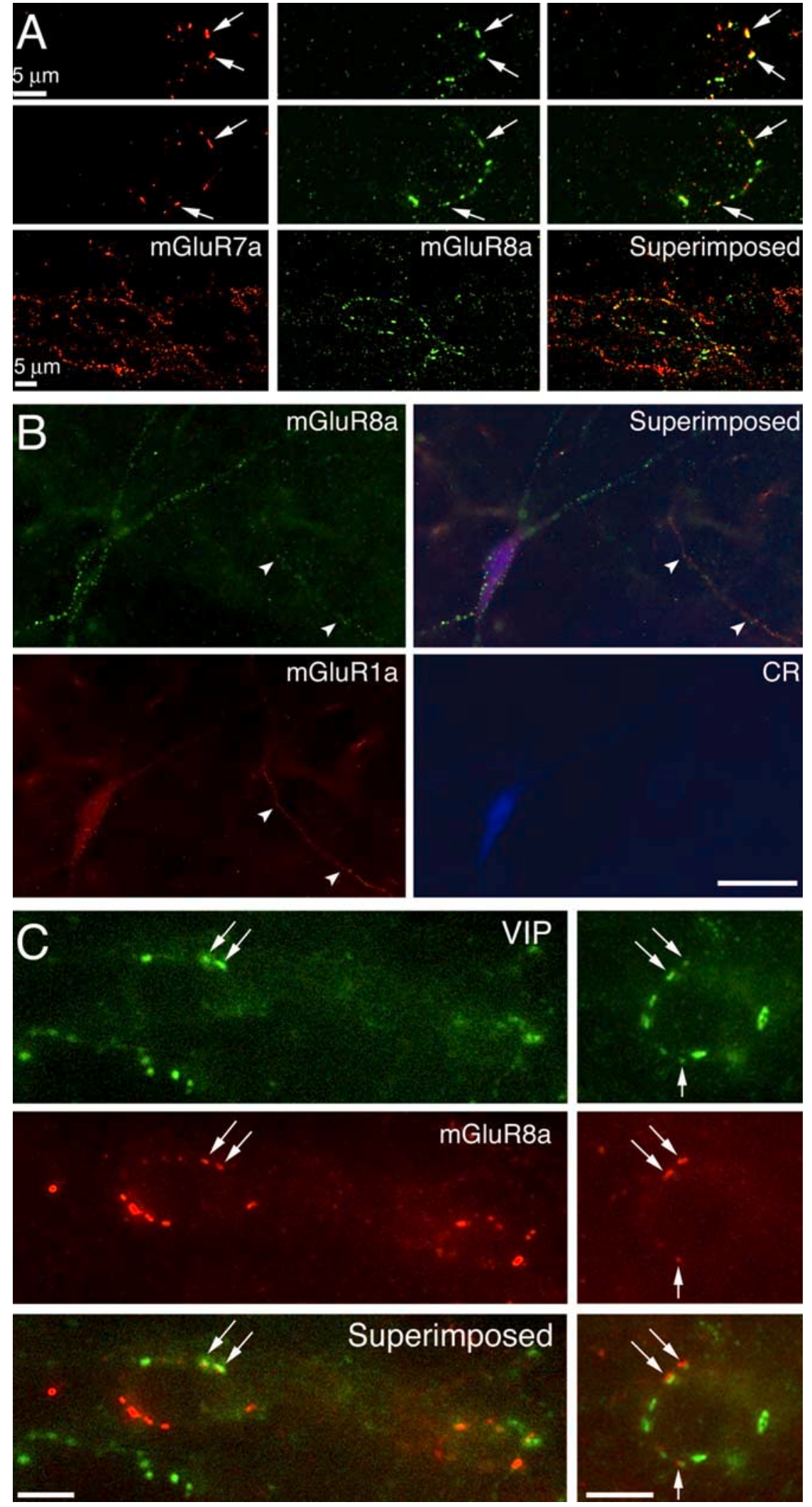

$\mathrm{CR}$

Figure 12. Targets of boutons coexpresssing mGluR8a and mGluR7a or VIP in the stratum oriens/alveus. $A$, Series of confocal microscopic images depicting mGluR8a-containing (green) and mGluR7a-containing (red) nerve terminals. In several boutons (arrows) the immunolabeling for mGluR8a and mGluR7a coexists, whereas other boutons contain only one receptor. Right, Superimposed images. $\boldsymbol{B}$, Series of images showing mGluR8a-containing (green) nerve terminals contacting the soma of an interneuron coexpressing mGluR1a (red) and CR (blue) and an mGluR1a-labeled dendrite (arrowheads). Top right, Superimposed images. $\boldsymbol{C}$, The soma of interneurons is innervated by boutons containing either VIP (green) or mGluR8a (red) or both molecules (arrows). Scale bars: $\boldsymbol{A}, 5 \mu \mathrm{m} ; \boldsymbol{B}, 50 \mu \mathrm{m} ; \boldsymbol{C}, 10 \mu \mathrm{m}$. 
In summary, we have demonstrated that mGluR8 is selectively distributed in the hippocampal formation, which can explain some of the complex and wide-ranging effects elicited by drugs acting on group III mGluRs and the subtle behavioral effects observed in mice lacking mGluR8.

\section{References}

Acsady L, Gorcs TJ, Freund TF (1996) Different populations of vasoactive intestinal polypeptide-immunoreactive interneurons are specialized to control pyramidal cells or interneurons in the hippocampus. Neuroscience 73:317-334.

Ali AB, Thomson AM (1998) Facilitating pyramid to horizontal oriensalveus interneurone inputs: dual intracellular recordings in slices of rat hippocampus. J Physiol (Lond) 507:185-199.

Allen YS, Adrian TE, Allen JM, Tatemoto K, Crow TJ, Bloom SR, Polak JM (1983) Neuropeptide $Y$ distribution in the rat brain. Science 221:877-879.

Amaral DG, Witter MP (1989) The three-dimensional organization of the hippocampal formation: a review of anatomical data. Neuroscience 31:571-591.

Baskys A, Malenka RC (1991) Agonists at metabotropic glutamate receptors presynaptically inhibit EPSCs in neonatal rat hippocampus. J Physiol (Lond) 444:687-701.

Baude A, Nusser Z, Roberts JD, Mulvihill E, Mcllhinney RA, Somogyi P (1993) The metabotropic glutamate receptor (mGluR1 alpha) is concentrated at perisynaptic membrane of neuronal subpopulations as detected by immunogold reaction. Neuron 11:771-787.

Blasco-Ibanez JM, Freund TF (1995) Synaptic input of horizontal interneurons in stratum oriens of the hippocampal CAl subfield: structural basis of feed-back activation. Eur J Neurosci 7:2170-2180.

Bradley SR, Levey AI, Hersch SM, Conn PJ (1996) Immunocytochemical localization of group III metabotropic glutamate receptors in the hippocampus with subtype-specific antibodies. J Neurosci 16:2044-2056.

Bushell TJ, Jane DE, Tse HW, Watkins JC, Garthwaite J, Collingridge GL (1996) Pharmacological antagonism of the actions of group II and III mGluR agonists in the lateral perforant path of rat hippocampal slices. Br J Pharmacol 117:1457-1462.

Cauli B, Porter JT, Tsuzuki K, Lambolez B, Rossier J, Quenet B, Audinat E (2000) Classification of fusiform neocortical interneurons based on unsupervised clustering. Proc Natl Acad Sci USA 97:6144-6149.

Conn PJ, Pin JP (1997) Pharmacology and functions of metabotropic glutamate receptors. Annu Rev Pharmacol Toxicol 37:205-237.

Cope DW, Maccaferri G, Marton LF, Roberts JD, Cobden PM, Somogyi P (2002) Cholecystokinin-immunopositive basket and Schaffer collateralassociated interneurones target different domains of pyramidal cells in the CA1 area of the rat hippocampus. Neuroscience 109:63-80.

Corti C, Restituito S, Rimland JM, Brabet I, Corsi M, Pin JP, Ferraguti F (1998) Cloning and characterization of alternative mRNA forms for the rat metabotropic glutamate receptors mGluR7 and mGluR8. Eur J Neurosci 10:3629-3641.

Corti C, Aldegheri L, Somogyi P, Ferraguti F (2002) Distribution and synaptic localisation of the metabotropic glutamate receptor 4 (mGluR4) in the rodent CNS. Neuroscience 110:403-420.

Csicsvari J, Hirase H, Czurko A, Buzsaki G (1998) Reliability and state dependence of pyramidal cell-interneuron synapses in the hippocampus: an ensemble approach in the behaving rat. Neuron 21:179-189.

Dalezios Y, Lujan R, Shigemoto R, Roberts JDB, Somogyi P (2001) Group III metabotropic glutamate receptors (mGluRs) on GABAergic terminals of hippocampal and neocortical interneurons. Soc Neurosci Abstr 27:259.5.

Dalezios Y, Lujan R, Shigemoto R, Roberts JD, Somogyi P (2002) Enrichment of mGluR7a in the presynaptic active zones of GABAergic and nonGABAergic terminals on interneurons in the rat somatosensory cortex. Cereb Cortex 12:961-974.

Desai MA, McBain CJ, Kauer JA, Conn PJ (1994) Metabotropic glutamate receptor-induced disinhibition is mediated by reduced transmission at excitatory synapses onto interneurons and inhibitory synapses onto pyramidal cells. Neurosci Lett 181:78-82.

Dolleman-Van Der Weel MJ, Witter MP (1996) Projections from the nucleus reuniens thalami to the entorhinal cortex, hippocampal field CA1, and the subiculum in the rat arise from different populations of neurons. J Comp Neurol 364:637-650.
Dumoulin A, Rostaing P, Bedet C, Levi S, Isambert MF, Henry JP, Triller A, Gasnier B (1999) Presence of the vesicular inhibitory amino acid transporter in GABAergic and glycinergic synaptic terminal boutons. J Cell Sci 112:811-823.

Duvoisin RM, Zhang C, Ramonell K (1995) A novel metabotropic glutamate receptor expressed in the retina and olfactory bulb. J Neurosci 15:3075-3083.

Evans DI, Jones RS, Woodhall G (2000) Activation of presynaptic group III metabotropic receptors enhances glutamate release in rat entorhinal cortex. J Neurophysiol 83:2519-2525.

Ferraguti F, Cobden P, Pollard M, Cope D, Shigemoto R, Watanabe M, Somogyi P (2004) Immunolocalization of metabotropic glutamate receptor 1alpha (mGluR1alpha) in distinct classes of interneuron in the CA1 region of the rat hippocampus. Hippocampus 14:193-215.

Freund TF, Buzsaki G (1996) Interneurons of the hippocampus. Hippocampus 6:347-470.

Ganter P, Szucs P, Paulsen O, Somogyi P (2004) Properties of horizontal axo-axonic cells in stratum oriens of the hippocampal CA1 area of rats in vitro. Hippocampus 14:232-243.

Gereau IV RW, Conn PJ (1995) Multiple presynaptic metabotropic glutamate receptors modulate excitatory and inhibitory synaptic transmission in hippocampal area CA1. J Neurosci 15:6879-6889.

Gerlai R, Adams B, Fitch T, Chaney S, Baez M (2002) Performance deficits of mGluR8 knockout mice in learning tasks: the effects of null mutation and the background genotype. Neuropharmacology 43:235-249.

Hajos N, Papp EC, Acsady L, Levey AI, Freund TF (1998) Distinct interneuron types express $\mathrm{m} 2$ muscarinic receptor immunoreactivity on their dendrites or axon terminals in the hippocampus. Neuroscience 82:355-376.

Joost P, Methner A (2002) Phylogenetic analysis of 277 human G-proteincoupled receptors as a tool for the prediction of orphan receptor ligands. Genome Biol 3:RESEARCH0063.

Kinoshita A, Ohishi H, Neki A, Nomura S, Shigemoto R, Takada M, Nakanishi S, Mizuno N (1996) Presynaptic localization of a metabotropic glutamate receptor, mGluR8, in the rhinencephalic areas: a light and electron microscope study in the rat. Neurosci Lett 207:61-64.

Klausberger T, Magill PJ, Marton LF, Roberts JD, Cobden PM, Buzsaki G, Somogyi P (2003) Brain-state- and cell-type-specific firing of hippocampal interneurons in vivo. Nature 421:844-848.

Klausberger T, Marton LF, Baude A, Roberts JD, Magill PJ, Somogyi P (2004) Spike timing of dendrite-targeting bistratified cells during hippocampal network oscillations in vivo. Nat Neurosci 7:41-47.

Kogo N, Dalezios Y, Capogna M, Ferraguti F, Shigemoto R, Somogyi P (2004) Depression of GABAergic input to identified hippocampal neurons by group III metabotropic glutamate receptors in the rat. Eur J Neurosci 19:2727-2740.

Linden AM, Johnson BG, Peters SC, Shannon HE, Tian M, Wang Y, Yu JL, Koster A, Baez M, Schoepp DD (2002) Increased anxiety-related behavior in mice deficient for metabotropic glutamate 8 (mGlu8) receptor. Neuropharmacology 43:251-259.

Losonczy A, Zhang L, Shigemoto R, Somogyi P, Nusser Z (2002) Cell type dependence and variability in the short-term plasticity of EPSCs in identified mouse hippocampal interneurones. J Physiol (Lond) 542:193-210.

Losonczy A, Somogyi P, Nusser Z (2003) Reduction of excitatory postsynaptic responses by persistently active metabotropic glutamate receptors in the hippocampus. J Neurophysiol 89:1910-1919.

Lujan R, Nusser Z, Roberts JD, Shigemoto R, Somogyi P (1996) Perisynaptic location of metabotropic glutamate receptors mGluR1 and mGluR5 on dendrites and dendritic spines in the rat hippocampus. Eur J Neurosci 8:1488-1500

Maccaferri G, Roberts JD, Szucs P, Cottingham CA, Somogyi P (2000) Cell surface domain specific postsynaptic currents evoked by identified GABAergic neurones in rat hippocampus in vitro. J Physiol (Lond) 524:91-116.

Malherbe P, Kratzeisen C, Lundstrom K, Richards JG, Faull RL, Mutel V (1999) Cloning and functional expression of alternative spliced variants of the human metabotropic glutamate receptor 8. Brain Res Mol Brain Res 67:201-210.

McBain CJ, DiChiara TJ, Kauer JA (1994) Activation of metabotropic glutamate receptors differentially affects two classes of hippocampal interneurons and potentiates excitatory synaptic transmission. J Neurosci 14:4433-4445.

Megias M, Emri Z, Freund TF, Gulyas AI (2001) Total number and distri- 
bution of inhibitory and excitatory synapses on hippocampal CA1 pyramidal cells. Neuroscience 102:527-540.

Messenger MJ, Dawson LG, Duty S (2002) Changes in metabotropic glutamate receptor 1-8 gene expression in the rodent basal ganglia motor loop following lesion of the nigrostriatal tract. Neuropharmacology 43:261-271.

Morino P, Herrera-Marschitz M, Castel MN, Ungerstedt U, Varro A, Dockray G, Hokfelt T (1994) Cholecystokinin in cortico-striatal neurons in the rat: immunohistochemical studies at the light and electron microscopical level. Eur J Neurosci 6:681-692.

Morishita W, Kirov SA, Alger BE (1998) Evidence for metabotropic glutamate receptor activation in the induction of depolarization-induced suppression of inhibition in hippocampal CA1. J Neurosci 18:4870-4882.

Nakanishi S, Masu M, Bessho Y, Nakajima Y, Hayashi Y, Shigemoto R (1994) Molecular diversity of glutamate receptors and their physiological functions. EXS 71:71-80.

Oe H, Miyashita K, Tanaka K, Naritomi H, Kinugawa H, Sawada T (1996) A case of progressive continuous muscular rigidity and painless and rhythmic muscle spasm associated with autoantibody against glutamic acid decarboxylase (in Japanese). Rinsho Shinkeigaku 36:1166-1171.

Ohishi H, Shigemoto R, Nakanishi S, Mizuno N (1993) Distribution of the messenger RNA for a metabotropic glutamate receptor, mGluR2, in the central nervous system of the rat. Neuroscience 53:1009-1018.

Pikkarainen M, Ronkko S, Savander V, Insausti R, Pitkanen A (1999) Projections from the lateral, basal, and accessory basal nuclei of the amygdala to the hippocampal formation in rat. J Comp Neurol 403:229-260.

Pinault D (1996) A novel single-cell staining procedure performed in vivo under electrophysiological control: morpho-functional features of juxtacellularly labeled thalamic cells and other central neurons with biocytin or neurobiotin. J Neurosci Methods 65:113-136.

Poncer JC, Shinozaki H, Miles R (1995) Dual modulation of synaptic inhibition by distinct metabotropic glutamate receptors in the rat hippocampus. J Physiol (Lond) 485:121-134.

Ranck Jr JB (1973) Studies on single neurons in dorsal hippocampal formation and septum in unrestrained rats. I. Behavioral correlates and firing repertoires. Exp Neurol 41:461-531.

Rosemond E, Peltekova V, Naples M, Thogersen H, Hampson DR (2002) Molecular determinants of high affinity binding to group III metabotropic glutamate receptors. J Biol Chem 277:7333-7340.

Saugstad JA, Kinzie JM, Shinohara MM, Segerson TP, Westbrook GL (1997) Cloning and expression of rat metabotropic glutamate receptor 8 reveals a distinct pharmacological profile. Mol Pharmacol 51:119-125.

Scanziani M, Gahwiler BH, Charpak S (1998) Target cell-specific modulation of transmitter release at terminals from a single axon. Proc Natl Acad Sci USA 95:12004-12009.

Schoepp DD (2001) Unveiling the functions of presynaptic metabotropic glutamate receptors in the central nervous system. J Pharmacol Exp Ther 299:12-20.

Schoepp DD, Jane DE, Monn JA (1999) Pharmacological agents acting at subtypes of metabotropic glutamate receptors. Neuropharmacology 38:1431-1476.
Semyanov A, Kullmann DM (2000) Modulation of GABAergic signaling among interneurons by metabotropic glutamate receptors. Neuron 25:663-672.

Shigemoto R, Mizuno N (2000) Metabotropic glutamate receptors-immunocytochemical and in situ hybridization analyses. In: Handbook of chemical neuroanatomy (Ottersen OP, Storm-Mathisen J, eds), pp 63-98. Amsterdam: Elsevier Science.

Shigemoto R, Nakanishi S, Mizuno N (1992) Distribution of the mRNA for a metabotropic glutamate receptor (mGluR1) in the central nervous system: an in situ hybridization study in adult and developing rat. J Comp Neurol 322:121-135.

Shigemoto R, Nakaya Y, Nomura S, Ogawa-Meguro R, Ohishi H, Kaneko T, Nakanishi S, Mizuno N (1993) Immunocytochemical localization of rat substance $P$ receptor in the striatum. Neurosci Lett 153:157-160.

Shigemoto R, Kulik A, Roberts JD, Ohishi H, Nusser Z, Kaneko T, Somogyi P (1996) Target-cell-specific concentration of a metabotropic glutamate receptor in the presynaptic active zone. Nature 381:523-525.

Shigemoto R, Kinoshita A, Wada E, Nomura S, Ohishi H, Takada M, Flor PJ, Neki A, Abe T, Nakanishi S, Mizuno N (1997) Differential presynaptic localization of metabotropic glutamate receptor subtypes in the rat hippocampus. J Neurosci 17:7503-7522.

Sik A, Penttonen M, Ylinen A, Buzsaki G (1995) Hippocampal CA1 interneurons: an in vivo intracellular labeling study. J Neurosci 15:6651-6665.

Somogyi J, Baude A, Omori Y, Shimizu H, Mestikawy SE, Fukaya M, Shigemoto R, Watanabe M, Somogyi P (2004) GABAergic basket cells expressing cholecystokinin contain vesicular glutamate transporter type 3 (VGLUT3) in their synaptic terminals in hippocampus and isocortex of the rat. Eur J Neurosci 19:552-569.

Somogyi P, Klausberger T (2005) Defined types of cortical interneurone structure space and spike timing in the hippocampus. J Physiol (Lond) 562:9-26.

Somogyi P, Dalezios Y, Lujan R, Roberts JD, Watanabe M, Shigemoto R (2003) High level of mGluR7 in the presynaptic active zones of select populations of GABAergic terminals innervating interneurons in the rat hippocampus. Eur J Neurosci 17:2503-2520.

Tamaru Y, Nomura S, Mizuno N, Shigemoto R (2001) Distribution of metabotropic glutamate receptor mGluR3 in the mouse CNS: differential location relative to pre- and postsynaptic sites. Neuroscience 106:481-503.

Vincent SR, McIntosh CH, Buchan AM, Brown JC (1985) Central somatostatin systems revealed with monoclonal antibodies. J Comp Neurol 238:169-186.

Wu S, Wright RA, Rockey PK, Burgett SG, Arnold JS, Rosteck Jr PR, Johnson BG, Schoepp DD, Belagaje RM (1998) Group III human metabotropic glutamate receptors 4, 7 and 8: molecular cloning, functional expression, and comparison of pharmacological properties in RGT cells. Brain Res Mol Brain Res 53:88-97.

Zhai J, Tian MT, Wang Y, Yu JL, Koster A, Baez M, Nisenbaum ES (2002) Modulation of lateral perforant path excitatory responses by metabotropic glutamate 8 (mGlu8) receptors. Neuropharmacology 43:223-230. 